\title{
The Effects of European Recommendations on the Validation of Lifelong Learning: A Quality Assurance Model for VET in Spain
}

\author{
Alfonso Redondo ${ }^{1, *} \mathbb{*}$, Salvador Castillo ${ }^{1} \mathbb{D}$, Luis Carro ${ }^{2}\left(\mathbb{D}\right.$ and Paulino Martín ${ }^{3}$ \\ 1 Department of Business Management and Market Research, School of Industrial Engineering, University of \\ Valladolid, Paseo del Cauce, 59, 47011 Valladolid, Spain; salvadorcastillorivera@gmail.com \\ 2 Department of Pedagogy, Faculty of Education and Social Work, University of Valladolid, Paseo de Belen, 1, \\ 47011 Valladolid, Spain; luis.carro@uva.es \\ 3 Head of Central Education Inspection, Consejería de Educación, Junta de Castilla y León, \\ 47006 Valladolid, Spain; paulino_martin@hotmail.com \\ * Correspondence: redondo@eii.uva.es
}

check for updates

Citation: Redondo, A.; Castillo, S.; Carro, L.; Martín, P. The Effects of European Recommendations on the Validation of Lifelong Learning: A Quality Assurance Model for VET in Spain. Sustainability 2021, 13, 7283. https://doi.org/10.3390/su13137283

Academic Editors: Ana B. Bernardo, Adrian Castro-Lopez, Javier Puente and Leandro Almeida

Received: 10 May 2021

Accepted: 23 June 2021

Published: 29 June 2021

Publisher's Note: MDPI stays neutral with regard to jurisdictional claims in published maps and institutional affiliations.

Copyright: (c) 2021 by the authors. Licensee MDPI, Basel, Switzerland. This article is an open access article distributed under the terms and conditions of the Creative Commons Attribution (CC BY) license (https:// creativecommons.org/licenses/by/ $4.0 /)$.

\begin{abstract}
Validation is an effective procedure for recognising the skills and knowledge acquired by individuals. However, the validation mechanisms in each country are not always easy to understand, especially due to a lack of information/data. The aim of this paper is to design a management system based on processes for the accreditation of professional competences acquired by work experience in Spain, considering European regulations. This is carried out through a contextualization of both regulatory frameworks through a bibliographic review, as well as the analysis of the quantitative and qualitative outcomes of the surveys that groups of experts involved in these tasks/procedures completed in Spain. All this has made it possible to design a model for the validation of learning acquired through professional experience as well as non-formal and informal channels in Europe and Spain, which facilitates the process of accreditation of competences.
\end{abstract}

Keywords: VET; European; validation principles; Spain

\section{Introduction}

In the field of Vocational Education and Training (VET), the importance of its professional development and validations are broadly acknowledged at national and international levels. Certification, validation, and identification are widely accepted mechanisms of recognition. Validation means the verification, by the qualified authority, of the outcomes of study obtained by a person in non-formal, formal, and informal education. Validation of the outcomes of non-formal adult education implicates the identification, evaluation and recognition of knowledge and skills a person obtains during life.

Strategic directions of validation of non-formal adult education have shown their significant role in the economy and society in general, allowing professional mobility, social integration, as well as the development of the concept of lifelong education [1]. Validation is an effective procedure to obtain qualifications that allows for recognition of the worker's knowledge; however, the validation mechanisms within each country are not well understood and the corresponding data are not sufficient. VET plays a relevant role in the change towards more knowledge-intensive societies. Indeed, around half of all jobs in 2020 will need a medium level qualification, which will be obtained by some form of VET [2].

In the 1970s, the United States of America raised an educational practice called prior learning assessment (PLA), also known as recognition of prior learning (RPL), assessment of prior learning (APL), prior learning assessment and recognition (PLAR), and validation of prior learning (VPL). This was carried out following research that displayed the viability of equating and assessing adults' prior non-college learning with college-level learning [3,4]. 
The increase of national qualifications frameworks at international levels has generated a supportive legislative and policy architecture for the development of PLA. Over the years, a wide range of practices have been established across the United Kingdom, North America, Scandinavia, New Zealand, Australia, and South Africa. Practices to test prior learning change from large-scale examinations to individual or learner petitioning. Postsecondary institutions have worked out their own approaches to PLA. The portfolio method is often implemented. In this approach, the apprentices display proof of their prior learning and give reasons as to how it relates to specific or general criteria. The access and/or credit are consequently conceded. Portfolios can be complemented using other assessment methods such as demonstrations, assigned essays, interviews, among others. Some PLA need learning from experience to join formal knowledge in a precise manner. Other practices run with the concept of equivalence; that is, determining that learning from experience is usually at the college level.

Terokhina [1] dealt with the issue of recognition of the results of non-formal adult education in the United States of America (USA) in order to be adopted by Ukraine. It was proposed to consider the College Level Examination Program (CLEP) and the credit system of the American Council on Education (ACE), since these are the mechanisms of non-formal adult education validation employed in USA. The process of validation can be assessing, discussion, demonstration of knowledge, training, interviewing, examination, communicative and social skills, critical reflection, expert explanations, simulations, declarative and portfolio methods.

The field of RPL in Quebec is being expanded due to the inclusion of different terminologies and policies established on the reality of contemporary Quebec society. A new stream of research associated to RPL and immigrant settlement and integration is starting to be more distinguished. The work recognized gaps in the research and recommended areas to encourage study, contributing to the field of scholarly endeavours of RPL. The conclusions from the consolidated RPL research should be a profit to the emerging field of RPL research [5].

Two issues in relation to assessment of prior learning were discussed by Aarkrog and Wahlgren [6]. These were the encounter of practical experience and school-based knowledge as well as the validity and reliability of the assessment procedures. The study showed that by mixing various assessment of prior learning methods and comparing the teachers' assessments, these address the issues of validity as well as reliability. In essence, it was discussed that validity and reliability can be boosted if the competencies are well established and the education system is aware of achieving a balance of knowing what, knowing why, and knowing how, given that teachers are appropriately qualified for the assessment procedures.

Paulos [7] studied the qualification of adult educators in Europe with special attention to Portugal. In this country, adult educators are a heterogeneous group. In the last decade, they have mainly worked in vocational training as well as in the recognition of prior learning. As a consequence, the professionalization of adult educators has been incipient, however, according to Guimarães [8], the profession of adult educator has never been organized. The unemployment of a part of the professionals implicated in adult education activities, especially in the recognition of prior learning process, has been due to the political disinvestment in the field of adult education that was carried out in the last few years. It should be relevant to guarantee the continuity of adult education policies to invest in the training of adult educators and secure stable employment situations, among others. These should be basic conditions for providing quality to adult education. Policies based on evidence should also be proposed to improve adult education. In addition, policies should include the valorisation of adult educators, allowing the creation of structured careers and their corresponding professional development.

Di Rienzo [9] carried out a study of empirical research completed in Italy. The interest was derived on the constant rising number of adults who were enrolled in graduate degree programmes. The research method joined qualitative and quantitative approaches, was 
composed of a national survey on the basis of a questionnaire sent to the Italian universities, and took methods of qualitative orientation. The survey aided to detect organisational procedures and instruments for the validation of prior vocational learning. Furthermore, it was able to state that it is only from the outlook of lifelong learning that universities were able to tackle the object at issue.

RPL will return to its legitimate position, if it is able to ensure the RPL candidates' accomplishment. As a consequence of this, Snyman \& van den Berg [10] set out the relevance of the profile of candidates. Empirical research was addressed, which involved the analysis of RPL candidates' life stories. The conclusion was that this requires an RPL approach that takes into account the significance of the outline at the apprentice, practitioner and institutional levels.

Werquin [11] analysed the recognition of non-formal and informal learning outcomes (RNFILO). This was pointed out as a policy tool and the possible applications and implementations were carried out. A definition of the key terms was put forward as well as a feasible rationale for organising recognition programmes and a schedule of pros and cons to carry them out.

More than 100 high-quality cases were put together on the state of validation of non-formal and informal learning (VNFIL) practices in 27 European countries as part of the Leonardo-OBSERVAL project. These covered specific strategies sustained in its implementation. Different topics were determined from this study and were selected to be analysed in the OBSERVAL-NET project. This project looked to sustain the development of comprehensive, coherent, and flexible models for VNFIL practices and recommendations as a result of a comparative study of samples of practice across European countries [12].

There are multiple experiences related to validation of learning in countries of the European environment, and these have been collected in various reports made by Cedefop under the title "European Inventory for Validation" [13-16]. A research project was completed in order to establish a common evaluation framework for Nordic countries (Iceland, Norway, Sweden, Finland, and Denmark). The project was structured in two phases, the first called "Quality in validation in the Nordic countries," where a context analysis was carried out, and the second part called "Quality Model for Validation in the Nordic countries. A development project 2012-13," in which a series of proposals were accomplished for the definition of a common model under the premise of quality [17]. The corresponding legislation in each country was studied and the references to the quality in these standards, the procedural development approaches from the operational point of view and how the quality could improve the procedure were also examined. The working group used the definition of quality given by the Canadian expert Van Kleef [18], which distinguished different aspects that could show a direct impact in the quality of the validation for these countries. These include:

- Laws, norms, regulations, etc.

- Policies

- Description of the validation system, organization, institutional affiliation, etc.

- $\quad$ The involved agents, organizations, labour market, etc.

- The skills of the validation professionals, certification, potential competence requirements and opportunities for the development of competences

- Methods for validation

In 2002, the EU began to tackle VET through a resolution approved by the Council called the "Copenhagen declaration" [19]. It requested the collaboration of the member states to improve VET systems. Two priorities could be highlighted: (a) to develop tools for mutual recognition and validation of competences and qualifications; and (b) to improve quality assurance in VET. In 2004, the contributions carried out two years earlier were confirmed and the established priorities were also developed (Maastricht Communiqué) [20]. Specific duties were entrusted to the member states. These include:

- Identification of common tools for the development of VET

- Development of the systems according to the needs of the people 
- Redefinition of open and various learning environments through VET frameworks, which allow mobility and validation between different levels and educational contexts - Implementation of quality assurance systems in VET in collaboration with all stakeholders

The first specific reference document on validation in Europe was raised in 2004, through a conclusions project called Common European Principles for the determination and validation of non-formal and informal education, in an effort to determine and validate differentiated learning [21]. This document arose in response to the European Council in Lisbon 2000 [22] to set out the challenge of making the European knowledge economy the most dynamic in the world, providing a special relevance to education and training.

The principles and validation elements of learning have been studied due to the accreditation procedure of competences and have had a heterogeneous development both in the European Union (EU) and Spain. This has not provided a response to the implantation of a validation system between the different European countries. The validation data collection from users of non-formal and informal learning is a major challenge and the demand for validation is increasing. Some exceptions have been noted in countries that have validation systems with a long tradition, like France and the Netherlands, where demand seems to have stabilized. This lack of data limits the opportunities for evaluation and control of validation activities.

It is important to understand the regulations that have been done at the European level in terms of validation as well as to the Spanish level in terms of accreditation. In Spain, there are several validation frames that cover various education levels: Qualifications and Vocational Training Act of 2002, Employment Act from 2003, Education Act from 2006, Higher Education Act from 2007, and Royal Decree 1224/2009 [23] on the recognition of professional competences acquired through work experience [14]. There was a joint call for validation in 2011 in order to implement the last decree. Most of the Autonomous Communities, with the exception of one, launched validation calls. The needs for accreditation have not been successfully dealt with, as well as the number of positions and the offer of existing qualifications in the National Catalogue of Professional Qualifications for the Spanish case. The principles and elements that determine the validation in European countries should be identified. The difference between the principles of validation should be presented according to the several international organizations such as UNESCO, European Council, and Cedefop, and the principles and elements that determine accreditation in Spain [24].

There is a shift between countries relative to the knowledge of VET, ranging from $46 \%$ to $91 \%$ of respondents. This displays a positive image in Europe, in relation to the capacity to make available job positions and prepare people for the workforce. Most respondents coincide that general education shows a more positive image than VET; $75 \%$ of Europeans agree with the statement that students with low grades are led to VET. However, the main country differences need further exploration to establish factors influencing the image of VET in different national contexts [25].

According to Cedefop [26], the implementation of validation arrangements is based on several interconnected steps. The main target of these guidelines is that validation is about: (a) how to attribute suitable value to results of non-formal and informal learning; and (b) how to show the results of non-formal and informal learning.

Quality assurance systems are capable of guaranteeing reliable, valid, and credible evaluations. Thus, they should be deepened in the research of this field. The connection between the national qualifications framework and the validation should be established deeper in order to write and to use learning outcomes for validation purposes [27]. As a consequence, the aims of this work are to review the validation framework of learning outcomes in Europe and Spain in order to characterize the validation of the acquired learning by professional experience in non-formal and informal learning, as well as to identify the development of the accreditation programme of competences in Spain.

The outline of the paper is as follows. Section two presents the theoretical framework; section three describes the methodology used; section four analyses the results; finally, section five summarizes the main conclusions. 


\section{Theoretical Framework}

The adoption and development of qualifications framework based on learning outcomes improve the situation of non-formal and informal learning in the labour market as well as in society. Focusing on the development of validation in the EU, the first official document of the EU that mentions the need of this recognition was the white book of the European Commission related to teaching and learning [28]. The preamble establishes the need to strengthen professional training policies as an element to improve the employability and competitiveness of the companies. Since then, the EU has shown an increasing interest related to the importance of the validation of all types of learning for its economic and social development. In the year 2000, the Lisbon European Council recognized that VET should be a tool that allows social inclusion, cohesion, mobility, employability, and competitiveness [19].

The following premises were used to develop the Directive relative to the recognition of professional qualifications [29]:

- Individual rights

- Obligations of the responsible

- Reliability and confidence

- Credibility and legitimacy

These premises allowed for the development of the recognition Directive of professional development [29], which confers the warrant to access the same profession and exercise it in other Member States with the same rights as nationals. It was also established to enhance the procedure to perform the recognition. This process was carried out through the Helsinki Communiqué (European Commission, 2006), which delved into and developed the highlights of the Copenhagen process, especially in terms of transparency, allowing ratification of the Europass and establishing the basis for the European Qualifications Framework (EQF), European Credit System for Vocational Education and Training (ECVET), and European Quality Assurance in Vocational Education and Training (EQAVET). In 2008, the priorities and strategies of the Copenhagen process were revised anew and it was called the Bordeaux Communiqué [30]. This was completed while keeping in mind the new objectives after 2010. In this same year, Cedefop published the European Training Thesaurus [31], which collects all the definitions in the field of vocational training to create a common language in the EU as a tool for the transparency and homologation of the concepts that are being used in each country. In 2009, Council of Ministers of the EU defined a new Framework for education and training. It was called Strategy 2020 [32], which enhanced the Lisbon objectives in 2010 seeking to improve VET, in order to raise employability and cohesion.

Four strategies were defined for which a set of 16 indicators were set up to perform their monitoring and evaluation. These were:

- Making reality learning throughout life and mobility

- Improving the quality and efficiency of education and training

- Promoting equity, social cohesion and active citizenship

- Consolidating creativity and innovation, including the entrepreneur skill, considering education and training levels

The following landmark in the field of validation was the publication by Cedefop of the Guidelines for the validation of informal and non-formal learning [26,33]. The directives were established, from the point of view of the public policies, in two perspectives. The first perspective establishes the need to coordinate the European principles defined in 2004 to support the development of quality assurance mechanisms, along with the principles of quality assurance and EQAVET Framework, using the tools designed (Europass, ECVET, EQF) to promote validation, comparability, and transparency of VET systems. The second perspective raises the validation process as part of the VET systems, and that the evaluation of the competition presents formative and summative components as well as the need to determine the sustainability of the process through cost-benefit analysis. 
The document defined the guidelines for validation, taking into account the principles mentioned previously, according to the following points:

- Individual rights. The process should be voluntary and egalitarian for access and evaluation, becoming the person at the centre of the procedure.

- Obligations of the responsible. Processes with the guarantee of quality should be established, which provide information as well as counselling to people about their rights, procedure, phases and outcomes. The transfer must also be ensured and provide access to formal VET systems.

- Reliability and confidence. Quality should ensure that the process is fair and transparent, considering reliable instruments and the professionalism of the consultants and evaluators.

- Credibility and legitimacy. These should be based on quality tools that ensure the participation of all those interested in the procedure as well as the recognition and the validity of the results.

In 2010, Bruges Communiqué ratified previous strategic axes in long-term VET [34]. From these perspectives, the following challenges for VET systems were posed:

- Flexibility and quality.

- Adaptation to the labour market and emerging needs.

- Boosting learning throughout life.

- Ensuring the sustainability and the excellence of the Education and Professional Training (EFP) through a common approach to quality control.

- Promoting the acquisition of essential competences.

These challenges are part of the Europe 2020 planning, which sought to set up new competencies among citizens, in order to face new social and economic models. This new European planning can be defined under the following lines of work:

- Innovation for the development of products and services.

- Mobility of young people, enhancing the performance of the education system, promoting non-formal and informal learning as well as the labour incorporation.

- Digital agenda for Europe; unique digital market access to the entire population.

- Effective use of resources with sustainable management in all areas.

- Industrial policy, competitiveness, globalization and social responsibility.

- Agenda for new qualifications and jobs, which improves employment, and training of workers and students.

- European platform against poverty, increasing cooperation between the member states. In 2012, the definitive encouragement to validation was produced from two different areas:

- UNESCO established directives for the recognition, validation and accreditation of different types of learning [35].

- The European Council's proposal for a Council Recommendation on the validation of non-formal and informal learning [36] where the factors indicated in the Europe 2020 Planning were defined, as well as the socio-economic crisis and young people unemployment.

Council Recommendation defined the validation as "a process by which an authorized organization confirms that a person has acquired learning outcomes, measured at a relevant level" [36]. The phases of the procedure were also specified:

- The identification of a person's particular experience through dialogue.

- The documentation that enables to make visible the experience of the person.

- A formal evaluation of that experience.

- The recognition of full or partial qualification, which leads to a certification.

The first Biennial of Validation of Prior Learning was held at Rotterdam in 2014. International experts reflected on the need to establish alliances throughout this process. Bjørnavold [37] presented an analysis of scope of the validation procedure to European 
level. It was explained that advances in policy, methodology, and practice and resources assignation were completed. However, the expectations were not reached according to the estimated initials. The principles that have to support the validation procedure according to Bjørnavold [37] are:

- The person is the centre of the validation system; this process is voluntary and the privacy of the person must be protected and respected. Moreover, an equitable and fair treatment must also be ensured.

- Information related to validation should be made available to the citizen. It will be provided in a coordinated manner and it will identify the different responsibilities between the agencies involved.

- Validation must be procedural and covers four main stages: identification, documentation, evaluation and certification of non-formal and informal learning.

- The validation process must be documented to facilitate transparency and recognition, using existing European and national tools.

- Guidance and advice are essential for people to be able to adapt validation to their needs and interests.

- The validation must be part of the vocational training systems. People should have the ability to obtain a degree, based on the validation of their learning outcomes.

- The validation criteria are defined and described through the learning outcomes formulated as knowledge, skills and competences. These will use the same standards as those defined to regulate formal learning.

- The quality assurance must be an explicit and integrated part of the validation processes, being reliable and transparent. Quality must also be at all stages of the validation process in a manner that ensures the reliability and duration of the entire process, from the identification of information to recognition.

- The training of professionals involved in the process must be ensured.

Validation must be a tool to enhance learning throughout the lifetime and the employability of people, especially for those with low qualifications and consequently with greater difficulties in the labour market, boosting the recognition of this tool between companies as a mechanism of professional career and continuous learning. Cedefop presented new guidelines, which were published throughout 2015 [26]. The aim was to specify the Council Recommendation [36] and to ease the implementation of the outcomes analysed by Cedefop in the different European Inventories on the Validation of learning. The new guidelines, based on the different sections of the Council Recommendation [13], defined validation as a procedure that allows for visibility and assesses the results obtained in different learning settings, without including formal education. Following the Recommendation, four phases can be established, such as determination, documentation, evaluation, and certification. However, it is constructed so that the citizen should not use all phases of the procedure. The first two phases can be considered as formative evaluation. Subsequently, it could be a formal evaluation and certification process, such as a summative evaluation. In this manner, the manager's goal is created, which is that the citizens can accredit their competences in a transparent and equitable manner. Unlike the Recommendation, it deals with and deepens the information and orientation phases, which indicates that it should be particularized, coordinated, and near to the citizen. This process is constituted as an essential tool for lifelong learning, which enables for the identification of professional competencies, interests, and personal skills in order to ease decision making and working [38]. Furthermore, it is established that the orientation will be part of the validation procedure, which should include tools such as continuous individual and collective services, specific websites, self-assessment systems, and the adaptation to the personal needs of each user. It is also established that the coordination between the different parties involved in all areas is a fundamental factor. For example, the strategy for the definition of public policies, the tactic for effective management of resources available, and the operation of the homogeneous management of the procedure. It affirms the need to define a legal framework that facilitates this coordination and regulates the procedure by attending to the different 
phases independently, determining the management tools by facilitating decision-making based on the needs and expectations of citizens.

The National Qualifications Frameworks should include the mechanisms of nonformal, informal, and formal training, and equivalent in European Credit for Vocational Education and Training (ECVET) [39].

Regarding those responsible for carrying out the procedures, it is important to establish the need to identify each group of interest, and define their functions and participation. Among those responsible, the following groups of interest are identified: (1) Counsellors; (2) Advisors, (3) Evaluators; (4) Managers of the procedure; and (5) Stakeholders: Politicians and Social agents (business associations, trade unions, volunteers, etc.).

The context in which the validation of learning should be developed is also defined. For this purpose, updates to the previous guidelines [33] and Council Recommendation [36] were introduced, aligned with the integration of this procedure in VET systems, and with the use of open resources of education (OER). This process started with a skills audit, including self-assessment questionnaires, and also the development of tools to detect needs of training.

Table 1 shows a comparison of Cedefop principles of 2009 [33] and 2015 [26], with respect to those of UNESCO [35] and Recommendation 2012 [36]. This will allow to determine the principles and validation elements that will be used later to carry out the research.

Table 1. Analysis of the validation according to European Recommendations.

\begin{tabular}{|c|c|c|c|c|}
\hline Document & Context & Principles & Recommendations & Phases \\
\hline $\begin{array}{c}\text { Common European } \\
\text { Principles } \\
18 / 05 / 2004\end{array}$ & $\begin{array}{l}\text { Recognition of education } \\
\text { and training as part of } \\
\text { economic and social } \\
\text { policies. } \\
\text { Recognition of the need to } \\
\text { ensure lifelong learning } \\
\text { - } \quad \text { Need to capitalize and } \\
\text { validate non-formal and } \\
\text { informal learning } \\
\text { Support for employability } \\
\text { and development of } \\
\text { human resources. }\end{array}$ & $\begin{array}{ll}\text { - } & \text { Individual rights. } \\
\text { Obligations of the } \\
\text { administration. } \\
\text { - } \quad \text { Reliability. } \\
\text { Credibility and } \\
\text { legitimacy. }\end{array}$ & $\begin{array}{l}\text { To broadcast European } \\
\text { principles. } \\
\text { Adaptation of the principles } \\
\text { to the specific needs of the } \\
\text { sectors. } \\
\text { - } \quad \text { Exchange of experiences. } \\
\text { To analysis how these } \\
\text { principles can support other } \\
\text { tools such as ECVET, EQF or } \\
\text { EQAVET. }\end{array}$ & $\begin{array}{l}\text { They are not } \\
\text { defined. }\end{array}$ \\
\hline $\begin{array}{c}\text { European } \\
\text { Directives } \\
04 / 11 / 2009\end{array}$ & $\begin{array}{l}\text { - Need to recognize the } \\
\text { learning outside of formal } \\
\text { systems. } \\
\text { - Strong economic and } \\
\text { employment development. } \\
\text { Detection of qualified } \\
\text { labour needs. }\end{array}$ & $\begin{array}{ll}\text { - } & \text { Voluntariness } \\
\text { - } & \text { Privacy. } \\
& \text { Access in equality } \\
\text { - } & \text { Participation. } \\
\text { - } & \text { Guidance and } \\
\text { - } & \text { advice. } \\
\text { Quality assurance } \\
\text { - } \quad \text { Imstems. } \\
\text { - } \\
\text { Regulation of the } \\
\text { evaluation results. }\end{array}$ & $\begin{array}{l}\text { Compatibility with the } \\
\text { Common European } \\
\text { Principles. } \\
\text { Development of the } \\
\text { European validation } \\
\text { inventory as a tool to } \\
\text { improve the guidelines and } \\
\text { the validation itself. } \\
\text { Validation must be part of } \\
\text { the vocational training } \\
\text { systems. } \\
\text { Formative and summative } \\
\text { approach of the evaluation } \\
\text { according to its purpose. } \\
\text { Normative development of } \\
\text { validation frameworks. } \\
\text { Sustainability of the system } \\
\text { with cost benefit analysis. } \\
\text { To use the same tools for } \\
\text { validation as formal training. }\end{array}$ & $\begin{array}{l}\text { - } \quad \text { Orientation } \\
\text { Evaluation of } \\
\text { individual } \\
\text { learning. } \\
\text { Audit of the } \\
\text { validation } \\
\text { process. }\end{array}$ \\
\hline
\end{tabular}


Table 1. Cont.

\begin{tabular}{|c|c|c|c|c|}
\hline Document & Context & Principles & Recommendations & Phases \\
\hline $\begin{array}{l}\text { Recommendations- } \\
\text { Validations } \\
20 / 12 / 2012\end{array}$ & $\begin{array}{l}\text { Importance of creating new } \\
\text { learning opportunities. } \\
\text { Introduction of non- } \\
\text { formal and informal } \\
\text { learning in } 2020 \text { Planning. } \\
\text { Validation as a mechanism } \\
\text { to access the labour } \\
\text { market. }\end{array}$ & $\begin{array}{ll}\text { - } & \text { Sustainable } \\
\text { integration in a } \\
\text { national } \\
\text { qualifications } \\
\text { framework. } \\
\text { - } \quad \text { Information. } \\
\text { - } \\
\text { dttention to the } \\
\text { disadvantaged. } \\
\text { Guidance and } \\
\text { - } \quad \text { Reasonable cost. } \\
\text { - } \quad \text { Quality. } \\
\text { Validation with } \\
\text { formal education. } \\
\text { Alignments with } \\
\text { other tools such as } \\
\text { Europass, ECTS, } \\
\text { ECVET. } \\
\text { Participation and } \\
\text { coordination. }\end{array}$ & $\begin{array}{l}\text { To ensure that exists national } \\
\text { validation systems in } 2015 . \\
\text { To support for national } \\
\text { qualifications frameworks. } \\
\text { To follow the common } \\
\text { principles of } 2004 . \\
\text { To exchange of good } \\
\text { practices. } \\
\text { - Cooperation between states. } \\
\text { Creation of instruments for } \\
\text { the transparency of the } \\
\text { procedure. }\end{array}$ & $\begin{array}{l}\text { Identification } \\
\text { of learning } \\
\text { outcomes. }\end{array}$ \\
\hline $\begin{array}{c}\text { New European } \\
\text { Directives } \\
2015\end{array}$ & $\begin{array}{l}\text { Economic crisis. } \\
\text { Low level of average } \\
\text { qualification throughout } \\
\text { Europe. } \\
\text { High dropout rate early } \\
\text { and failure educational. } \\
\text { - Compliance of validation } \\
\text { recommendation } 2012 . \\
\text { Need to use open } \\
\text { educational resources for } \\
\text { validation. } \\
\text { Use of validation in } \\
\text { companies. }\end{array}$ & $\begin{array}{l}\text { Centrality in the } \\
\text { person. } \\
\text { Information } \\
\text { guidance and } \\
\text { advice. } \\
\text { Social } \\
\text { responsibility. } \\
\text { Definition of legal } \\
\text { frameworks. } \\
\text { - Coordination. } \\
\text { Access, transfer } \\
\text { and accumulation } \\
\text { of outcomes. }\end{array}$ & $\begin{array}{l}\text { Adaptation of phases } \\
\text { independently depending on } \\
\text { the objective. } \\
\text { Use of tools for validation } \\
\text { according to the purpose. } \\
\text { - } \quad \text { Formative and summative } \\
\text { evaluation. } \\
\text { - } \quad \text { Detection of needs. } \\
\text { Integration with national } \\
\text { frameworks. } \\
\text { Use of the same standards as } \\
\text { for formal training. } \\
\text { Training of the staff } \\
\text { responsible of the process. } \\
\text { Audit of skills and labour } \\
\text { market. }\end{array}$ & 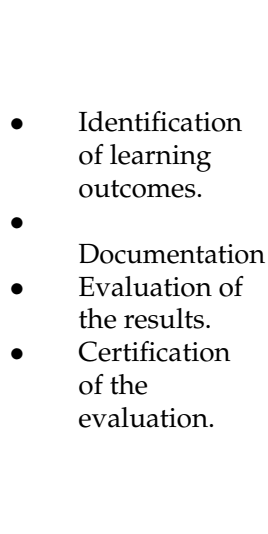 \\
\hline
\end{tabular}

The major landmarks on the validation procedure are highlighted:

- Common European Principles for the determination and validation of non-formal and informal education (Council of the EU 9600/04 EDUC 118 SOC 253, 18 May 2004).

- European Guidelines for the validation of non-formal and informal learning of Cedefop in 2009 [33].

- Council Recommendation on the validation of non-formal and informal learning [36].

- The proposal of the new Cedefop Guidelines that were published in 2015 [26].

The result of the analysis of the documents described previously is displayed in Table 1. Included are the context in which the recommendation is dictated; the principles that it collects; recommendations that it provides; and the phases that determine the procedure.

VET is associated with education that prepares people for a specific occupation. The opening of the market for training and education, including VET, has raised the relevance of regulation and quality assurance mechanisms to ensure the integrity of qualifications. Misko [40] studied the approaches to the regulation and quality assurance of VET in a number of countries, including New Zealand, Canada (province of Ontario) and two accrediting agencies in USA, as well as selected European member states such as Finland, Sweden, and the United Kingdom. Therefore, the practices imposed overseas can be used to report the development of VET regulatory and quality assurance approaches in Australia.

The openness of the School-to-Work Opportunities Act involved large opportunities for USA, since it had different regional and local models of vocational training. Regarding 
the changing conditions of a globalised economy, the tech-prep is a suitable example for fitting the traditional school-based vocational education. By matching high school and community college courses, students can meet the growing demand for an extensive knowledge base and problem-solving qualifications [41].

The transfer of VET systems is the subject of international debate, however, there is no sufficient documentation related to the process or study of how such transfers are obtained in practical terms. Pilz [42] studied the potential for devolving Germany's dual vocational training system to German subsidiaries in foreign parts, specifically in Japan, USA, India, and China. The work arranged the range of training strategies established by German subsidiaries. Interviews in more than 40 German subsidiaries abroad showed that local factors in the host country play such an important role that it is not feasible to transfer the German VET system completely to another country. As a result, the findings showed that policy borrowing in the area of VET is presumed to be only partial and will be markedly influenced by the national features of the host country. Furthermore, the vocational and training performance of German corporations at their subsidiaries in China, India, and USA has been dealt with. These three countries present relevant markets for Germany and they are characterised by their varied cultures, employment systems, and VET. The transfer of the German VET system to other countries has also been a subject of study [43].

Switzerland is one of several European countries with a so-called "dual" VET system in which students blend learning in school with learning in workplace settings. In Denmark, Norway, Austria, Switzerland, and Germany, between 30 and 70 percent of students in upper secondary school are involved in such systems. VET is the mainstream upper secondary programme, serving 70 percent of Swiss young people. It teaches a broad set of students including high-tech, health, human service, and traditional trades as well as crafts. One measure of the power of that economy is that Switzerland presents practically full employment, with a youth unemployment ratio that is the lowest among developed countries [44].

VET systems change significantly from country to country due to their present different objectives and because they are embedded within the education and labour market systems of any country. There are typologies that characterise and compare VET systems. However, many of them show weaknesses related to the consistency of their descriptive criteria or, for example, the extent to which the typology can deal with more complex VET systems. Therefore, a new typology that builds on existing approaches from a range of disciplines should be developed. Pilz [45] has put forward a novel typology which allows VET systems in a range of countries to be organized across the different levels involved, in aspects as varied as curriculum design, teaching practices and government regulation. Six countries, Germany, France, India, Japan, China and the USA, are selected as case studies. These have demonstrated sizeable differences but also biased convergences. The typology proposes a framework for explanatory approaches in individual country contexts as well as an opportunity for international comparison of key aspects of VET systems, the possible transfer of VET models from one country to another, and the value enclosed to vocational qualifications.

\section{Methodology}

Research presents three clearly identified parts that condition the methodology to be followed in each case [46]. These phases are: Definition of the investigation, Research work or field work, and Analysis of the results.

The scheme used in the first phase is shown in Figure 1. It consists of the need to set up working groups, exchange research objectives, and the management of all documentation that will be used in the process [47]. 


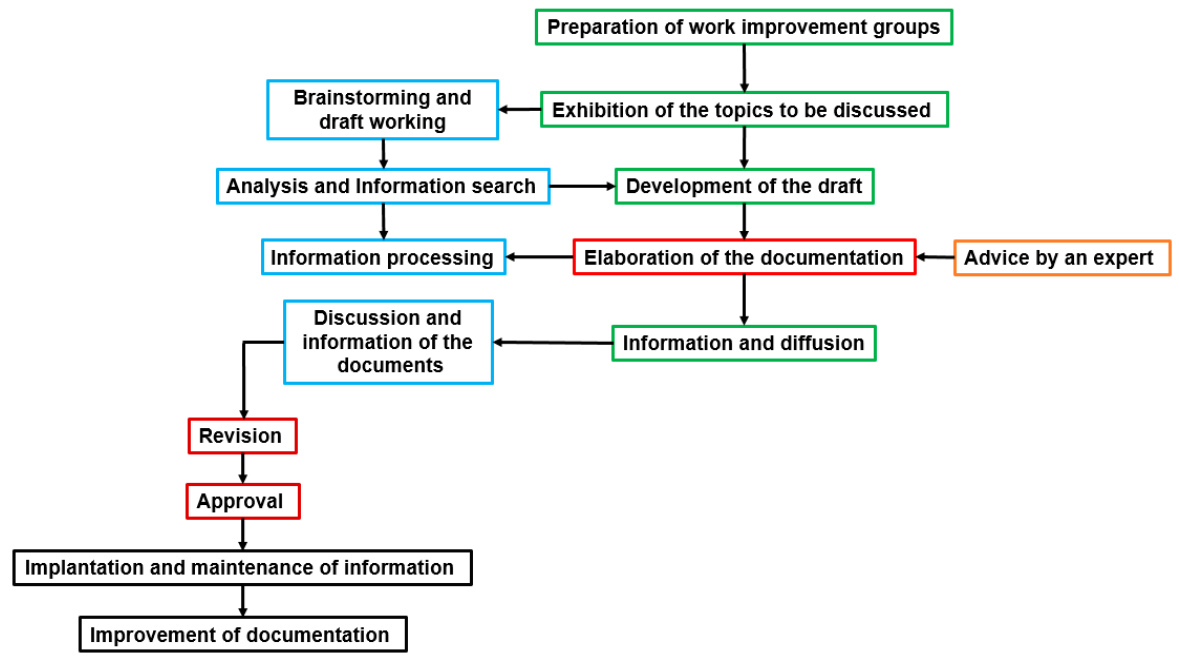

Figure 1. Definition of the research [47]. Green framing is associated to coordinating team; blue (quality groups or improvement); red (key activity); orange (external staff); dark red (quality committee or improvement); and finally, black (all levels).

The entire procedure for the collection of this information must be processed [48] in order to ensure homogeneity in the request, search, and the management of the information (see Figure 2a-c).

For the methodological development of the second phase of the research project, two tools are considered: one of them qualitative and another quantitative [49]. Documentary analysis [50] is used in the qualitative part in order to extract the main aspects of the whole documentation which will be reviewed with the objective to synthesize subsequently the common elements in the scope of the study. The elaboration of a questionnaire is chosen in the quantitative part [51]. This consists of two parts, one closed for data contributions, and another opened to collect the qualification of the respondents on the different phases of accreditation procedure. Once the documentation and information required has been determined, data collection and analysis for both qualitative and quantitative parts proceeds. The range of the regulatory framework should be marked out in a European and Spanish environment. In this phase of research work, the selection and comparison of the different and extensive documentation will be completed [52]. The outcomes will be collected in tables that allow for comparison of the study items with the extracted data from each of them. It will also determine the sample for the execution of the quantitative part [53] based on the analysis of the calls carried out in Spain and taking into account the items extracted from RD 1224/2009 [23], which constitutes the frame of reference for this work. In the analysis of the results, the complexity consists of the integration of quantitative and qualitative results, which are derived from the surveys to the Autonomous Communities regarding the different phases of the procedure. The final aim should be to identify the results of the procedure operation, from the regulatory development in 2009 to the calls held in 2013. 


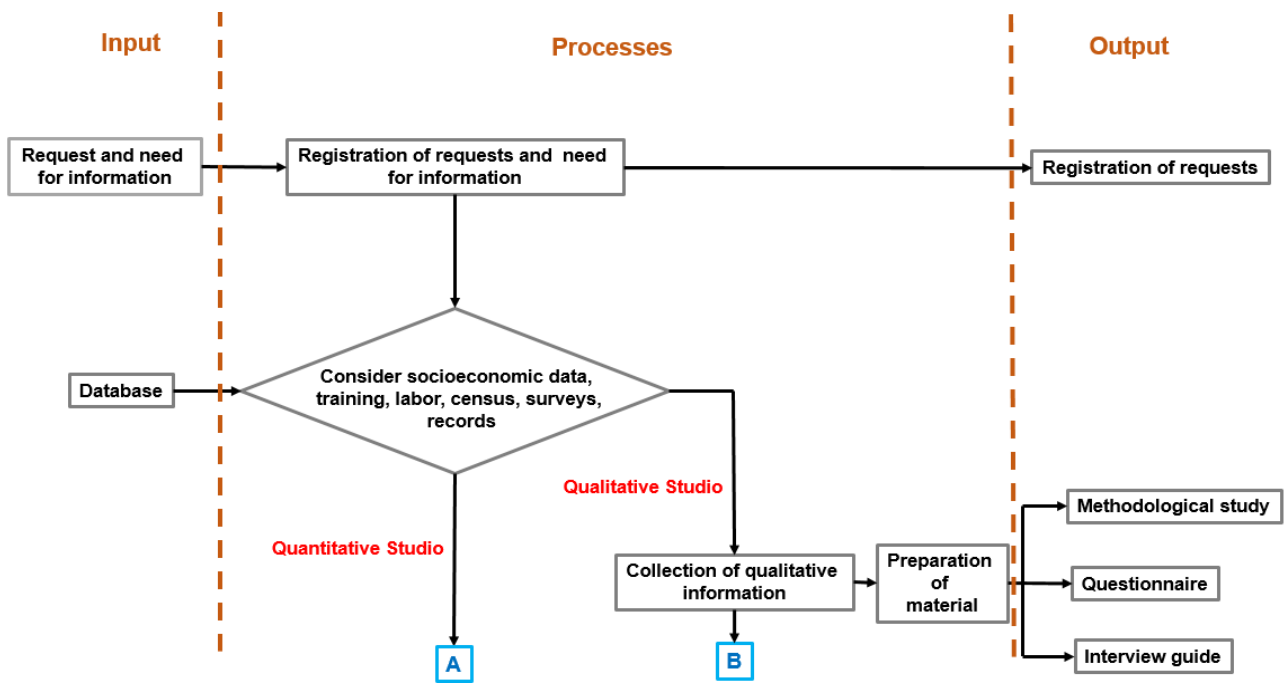

(a)

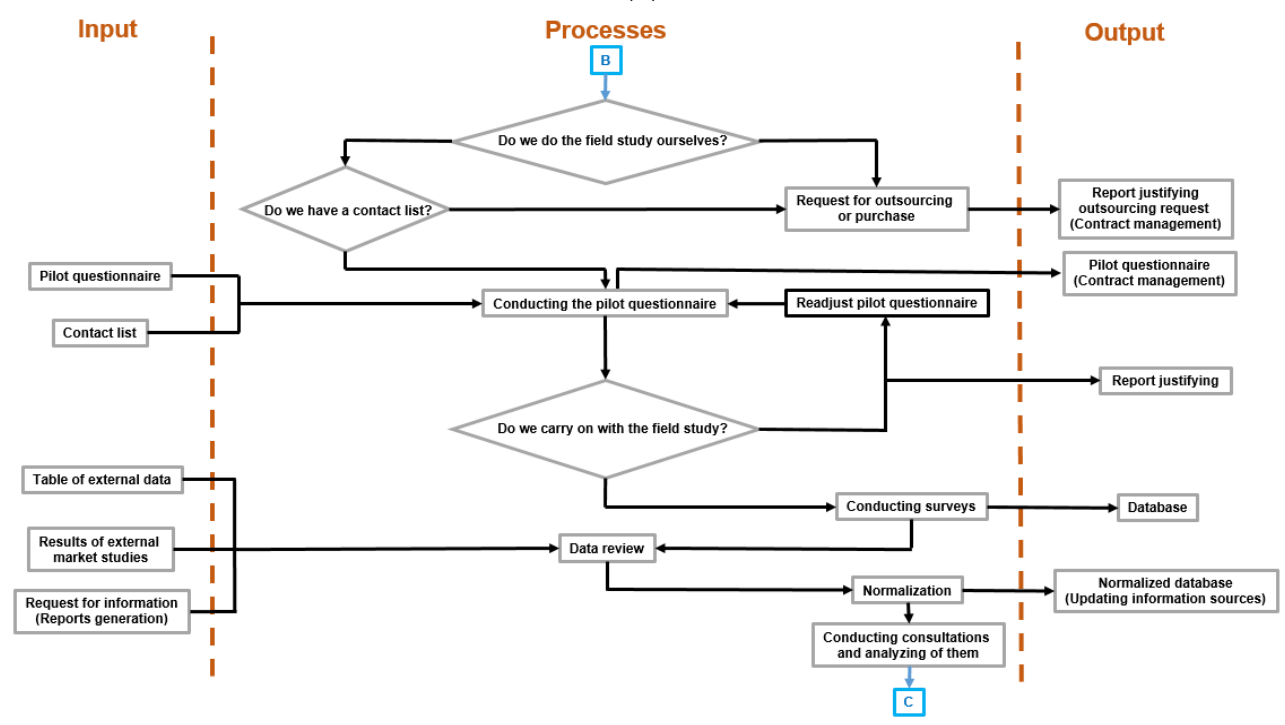

(b)

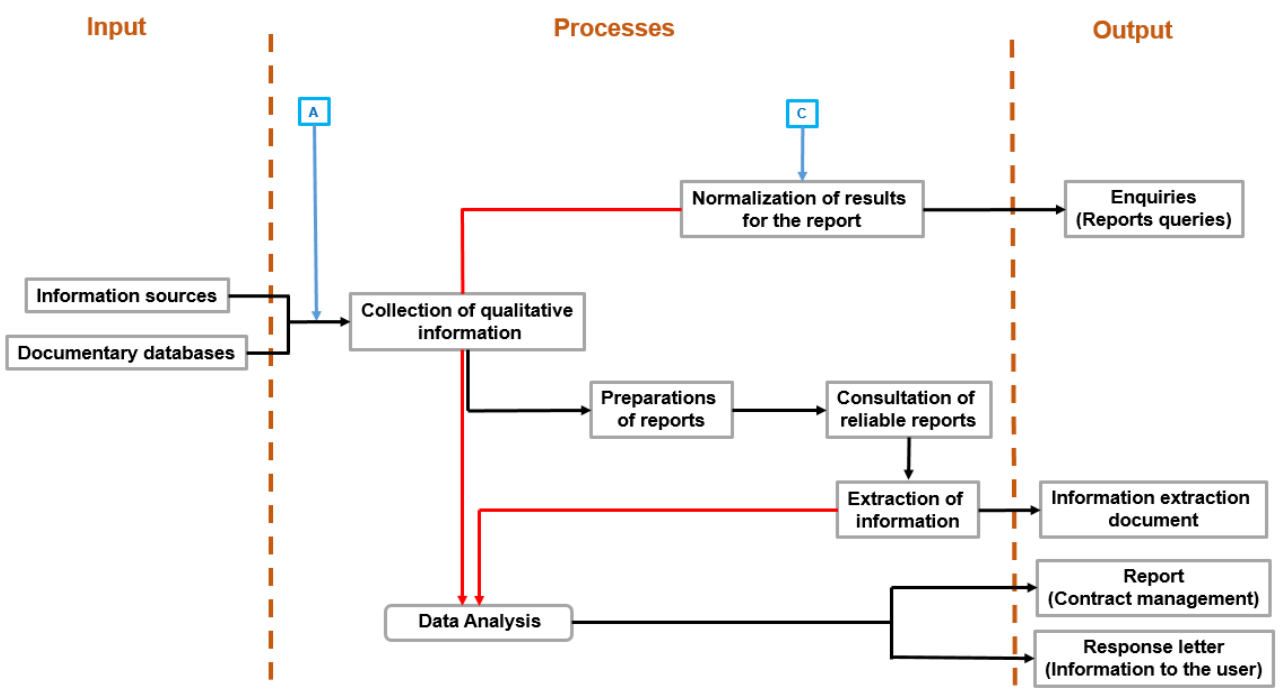

(c)

Figure 2. (a) Information management procedure flowchart. Start. (b) Information management procedure flowchart. Medium. (c) Information management procedure flowchart. Final. 
Finally, qualitative information treatment is carried out using SWOT (Strengths, Weaknesses, Opportunities, and Threats) analysis. This is to determine the relevant points and the improvement areas of the same, as a starting point for the realization of a proposal of a management system model [54] based on processes for the accreditation procedure of competencies in Spain. Some items should be considered to perform an analysis that provides information to assess the aims compliance of the National System of Qualifications and Vocational Training; in particular, the procedure of competencies accreditation. These include:

- Diagnosis of the validation procedure status in Europe and Spain

- Documentary analysis of the regulations for the procedure development in the Autonomous Communities

- Analysis of the calls carried out in the Autonomous Communities

- Diagnosis of positions offered for the accreditation and the qualifications convened as well as the public resources used

- Preparation of Instruments/Forms for diagnosis

- Field of work: obtaining the required information

- Analysis of the information collected

- Preparation of a report about the accreditation procedure in Spain

The goal is to obtain information to analyse the system using systematic procedures, based on quality criteria that allows to perform the final evaluation report and the improved proposal of the system. A specific evaluation of this procedure will be completed, directed to identify the degree of development, adaptation, and homogenization in the process of implementation of the different appropriate Administrations.

Figure 3 summarizes the proposal for a comprehensive management system based on integral, operational, and strategic control processes, for the procedure of recognition, evaluation, and registration of competences.

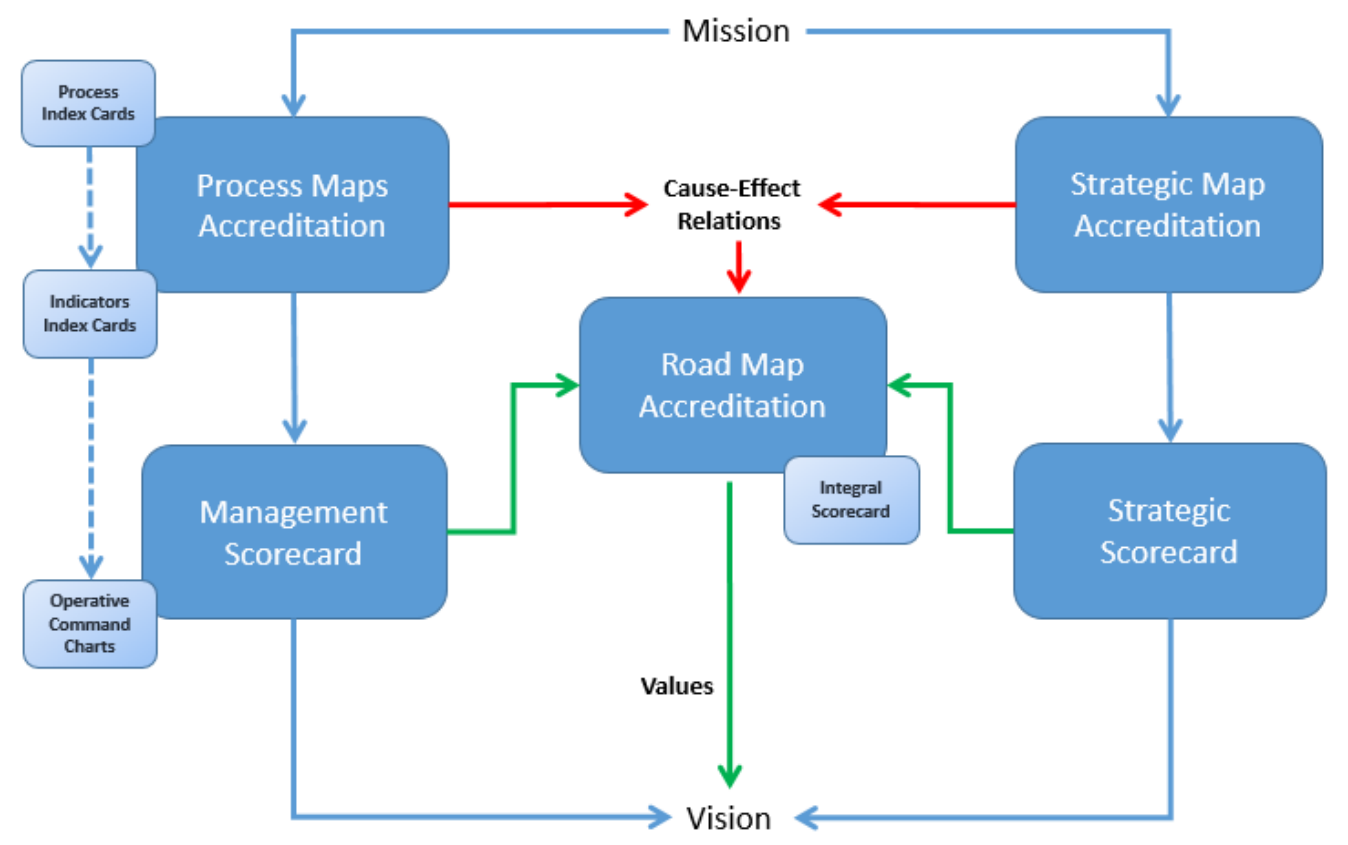

Figure 3. Comprehensive management model for the accreditation procedure.

\section{Results}

This section responds to the planning of the research study, which aims to determine the validation principles and elements of the learning in the different regulations. Thus, the validation procedure that has been developed in the EU and Spain should be studied in order to obtain their recommendations and conclusions. This is carried out using the theoretical framework reviewed previously, along with data collected in Table 2. 
Table 2. Analysis of the validation according to European Recommendations.

\begin{tabular}{|c|c|c|c|c|c|}
\hline & Principles 2004 & Directives 2009 & $\begin{array}{c}\text { Directives } \\
\text { UNESCO } 2009\end{array}$ & $\begin{array}{l}\text { Recommendations } \\
2013\end{array}$ & Directives Project 2016 \\
\hline $\begin{array}{l}\text { Individual } \\
\text { Rights }\end{array}$ & Individual rights & $\begin{array}{c}\text { Voluntariness, } \\
\text { privacy and access } \\
\text { in equality and } \\
\text { equity. }\end{array}$ & $\begin{array}{l}\text { Validation as an } \\
\text { Essential } \\
\text { complement of LLL }\end{array}$ & & $\begin{array}{l}\text { The person is the centre of } \\
\text { the validation process. }\end{array}$ \\
\hline $\begin{array}{l}\text { Credibility } \\
\text { and } \\
\text { Legitimacy }\end{array}$ & $\begin{array}{l}\text { Credibility } \\
\text { and } \\
\text { legitimacy }\end{array}$ & $\begin{array}{l}\text { Impartiality and } \\
\text { Regulation of the } \\
\text { evaluation results. }\end{array}$ & & $\begin{array}{c}\text { Alignment with other } \\
\text { tools such as } \\
\text { Europass, ECTS, } \\
\text { ECVET }\end{array}$ & $\begin{array}{l}\text { The qualification criteria } \\
\text { are defined and described } \\
\text { through the learning } \\
\text { outcomes as knowledge, } \\
\text { skills and competences. }\end{array}$ \\
\hline $\begin{array}{l}\text { Reliability } \\
\quad \text { and } \\
\text { Confidence }\end{array}$ & $\begin{array}{l}\text { Reliability } \\
\text { and } \\
\text { confidence }\end{array}$ & $\begin{array}{l}\text { Quality assurance } \\
\text { systems }\end{array}$ & & $\begin{array}{l}\text { Quality systems will } \\
\text { be used to ensure the } \\
\text { reliability, validity } \\
\text { and credibility of the } \\
\text { process. }\end{array}$ & $\begin{array}{l}\text { Quality assurance must be } \\
\text { an explicit and integrated } \\
\text { part of the validation } \\
\text { process. }\end{array}$ \\
\hline $\begin{array}{l}\text { Obligations } \\
\text { of the } \\
\text { Responsible }\end{array}$ & $\begin{array}{l}\text { Obligations } \\
\text { of the } \\
\text { responsible }\end{array}$ & $\begin{array}{l}\text { Guidance and } \\
\text { advising }\end{array}$ & $\begin{array}{l}\text { Training of the } \\
\text { responsible of the } \\
\text { validation process. } \\
\text { Economic } \\
\text { sustainability of the } \\
\text { validation systems. }\end{array}$ & Sustainable cost & $\begin{array}{l}\text { The professional } \\
\text { competencies of the } \\
\text { validation counsellors and } \\
\text { evaluators should be } \\
\text { developed. }\end{array}$ \\
\hline Information & & & $\begin{array}{l}\text { Accessibility of the } \\
\text { validation systems. }\end{array}$ & $\begin{array}{l}\text { Information } \\
\text { procedures will be } \\
\text { defined, about the } \\
\text { process and their } \\
\text { outcomes }\end{array}$ & $\begin{array}{l}\text { Information about } \\
\text { validation should be made } \\
\text { available, close the place } \\
\text { where citizens live. }\end{array}$ \\
\hline $\begin{array}{c}\text { Identification } \\
\text { of the } \\
\text { Phases }\end{array}$ & & & & $\begin{array}{l}\text { Elements that allow } \\
\text { to determine, to } \\
\text { document and to } \\
\text { evaluate as well as to } \\
\text { certify learning } \\
\text { outcomes, equal to } \\
\text { those of formal } \\
\text { education. }\end{array}$ & $\begin{array}{l}\text { Validation has different } \\
\text { purposes and four main } \\
\text { stages. }\end{array}$ \\
\hline $\begin{array}{l}\text { Orientation } \\
\text { and } \\
\text { Advice }\end{array}$ & & & & $\begin{array}{c}\text { Guidance and } \\
\text { advising procedures } \\
\text { will be defined on the } \\
\text { process and their } \\
\text { results. }\end{array}$ & $\begin{array}{l}\text { Guidance and advising are } \\
\text { essential for people to be } \\
\text { able to adapt validation to } \\
\text { their needs. }\end{array}$ \\
\hline $\begin{array}{c}\text { Integration } \\
\text { in } \\
\text { National Frame }\end{array}$ & & & $\begin{array}{l}\text { Validation as part } \\
\text { of the VET systems. }\end{array}$ & $\begin{array}{c}\text { Sustainable } \\
\text { integration in a } \\
\text { national } \\
\text { qualifications } \\
\text { framework. }\end{array}$ & $\begin{array}{l}\text { Validation should be part of } \\
\text { systems and national } \\
\text { qualifications frameworks. }\end{array}$ \\
\hline Employability & & & & & $\begin{array}{l}\text { Validation must fortify the } \\
\text { employability of people. }\end{array}$ \\
\hline $\begin{array}{c}\text { Documentation of } \\
\text { the } \\
\text { Process }\end{array}$ & & & & & $\begin{array}{l}\text { The validation } \\
\text { documentation. }\end{array}$ \\
\hline $\begin{array}{l}\text { Participation } \\
\text { and } \\
\text { Coordination }\end{array}$ & & Participation & $\begin{array}{l}\text { Coordination and } \\
\text { integration of } \\
\text { stakeholders. }\end{array}$ & $\begin{array}{c}\text { To promote the } \\
\text { participation, } \\
\text { collaboration and } \\
\text { coordination of the } \\
\text { different } \\
\text { stakeholders, } \\
\text { companies and the } \\
\text { VET supplier centres. }\end{array}$ & $\begin{array}{l}\text { GI coordination from the } \\
\text { definition of the legal } \\
\text { framework, the } \\
\text { organization and procedure } \\
\text { management as well as the } \\
\text { detection of needs. }\end{array}$ \\
\hline
\end{tabular}

From this, the aforementioned principles and elements were extracted, which have been reflected in the models of corresponding records for each geographical area, the European (Table 3) and the Spanish (Table 4). 
Table 3. Principles and elements of validation according to European recommendations and guidelines.

Principles and elements of the validation of the learnings. Research technique: Comparative analysis. Study parameters: Principles and validation elements. Study units: Recommendations and Guidelines on

Validations according to the EU.

\begin{tabular}{ll}
\hline \multicolumn{1}{c}{ Categories } & \multicolumn{1}{c}{ Variables } \\
\hline \multirow{3}{*}{ Principles } & Individual rights \\
\cline { 2 - 2 } & Credibility and legitimacy \\
\cline { 2 - 2 } & Reliability and confidence \\
\cline { 2 - 2 } & Obligations of those responsible \\
\hline & Information \\
\cline { 2 - 2 } & Identification of the phases \\
\hline & Guidance and advice \\
\hline & Employability \\
\hline & Documentation of the process \\
\hline & Participation and coordination \\
\hline
\end{tabular}

Table 4. Principles and elements of validation according to Spanish regulations.

\begin{tabular}{|c|c|c|}
\hline Categories & Variables & Attributes \\
\hline \multirow{11}{*}{ Regulation } & Date & Year \\
\hline & \multirow{2}{*}{ Type of Regulation } & Normative \\
\hline & & Announcement \\
\hline & \multirow{4}{*}{ Competent organ } & Educative administration \\
\hline & & Labour administration \\
\hline & & Both \\
\hline & & Others \\
\hline & \multirow{4}{*}{ Regulatory status } & Decree \\
\hline & & Order \\
\hline & & Resolution \\
\hline & & Others \\
\hline \multirow{11}{*}{ Framework } & \multirow{7}{*}{ European } & Permanent learning \\
\hline & & Validation of learning \\
\hline & & Mobility \\
\hline & & Employability \\
\hline & & Competitiveness \\
\hline & & Flexibility of itineraries \\
\hline & & EQAVET Framework \\
\hline & \multirow{4}{*}{ Spanish } & Personal development throughout life \\
\hline & & Attention needs productive system \\
\hline & & Participation and cooperation agents involved \\
\hline & & Adaptation of EU criteria \\
\hline \multirow{9}{*}{ Validation Principles } & Person centre of the process & \\
\hline & Next information & \\
\hline & Adapted orientation & \\
\hline & Independent stages & \\
\hline & Integration National frameworks & \\
\hline & Competences recognition & \\
\hline & Training of human resources & \\
\hline & Obligations of those responsible & \\
\hline & Processes documentation & \\
\hline
\end{tabular}




\subsection{Analysis of the Validation Principles in European Recommendations}

A study has been carried out on the principles and elements included in the different recommendations and guidelines existing in Europe, see Table 2. This is a prior step to the preparation of the results present in Table 5.

Table 5. Comparative analysis of the validation principles and elements according to the European recommendations.

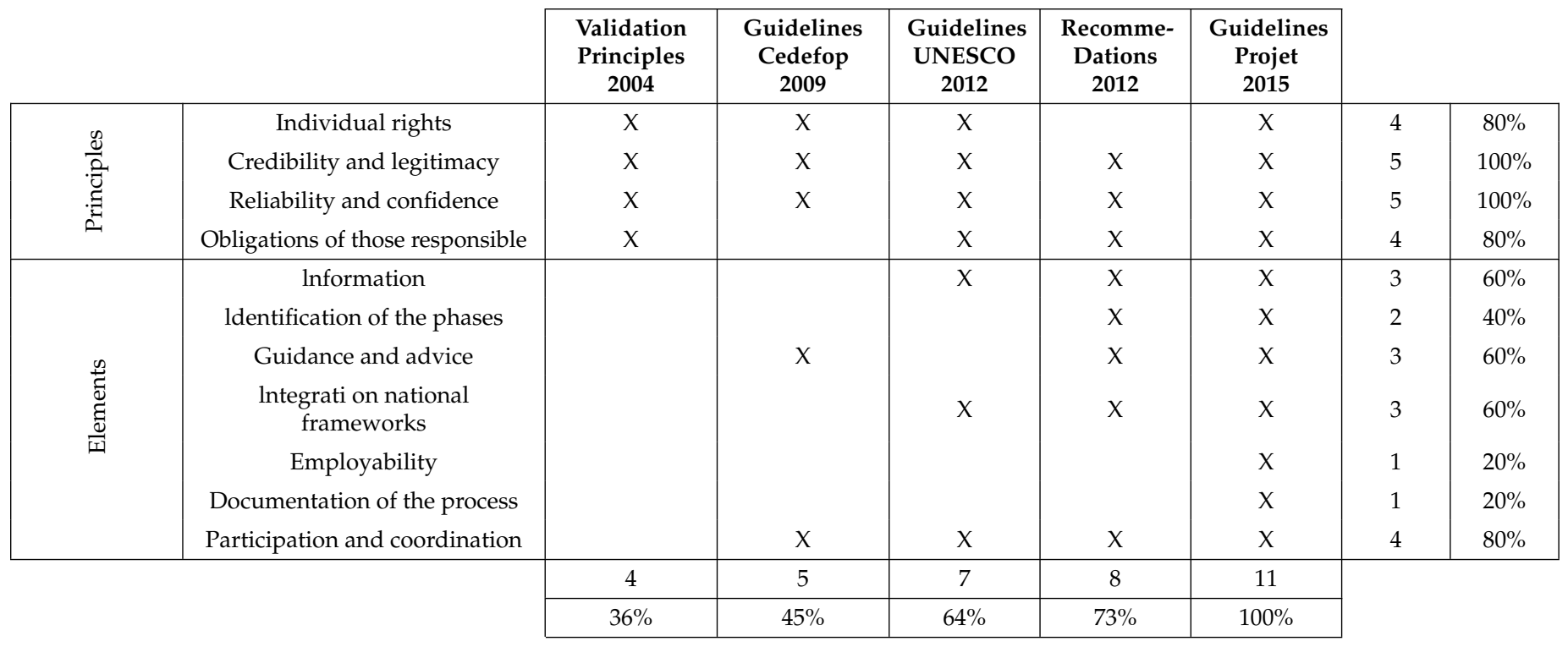

Considering the two entries in Table 5, an analysis is carried out. The percentage of each element is collected, see Figure 4. As shown, credibility, legitimacy, reliability, and confidence are presented in all references studied.

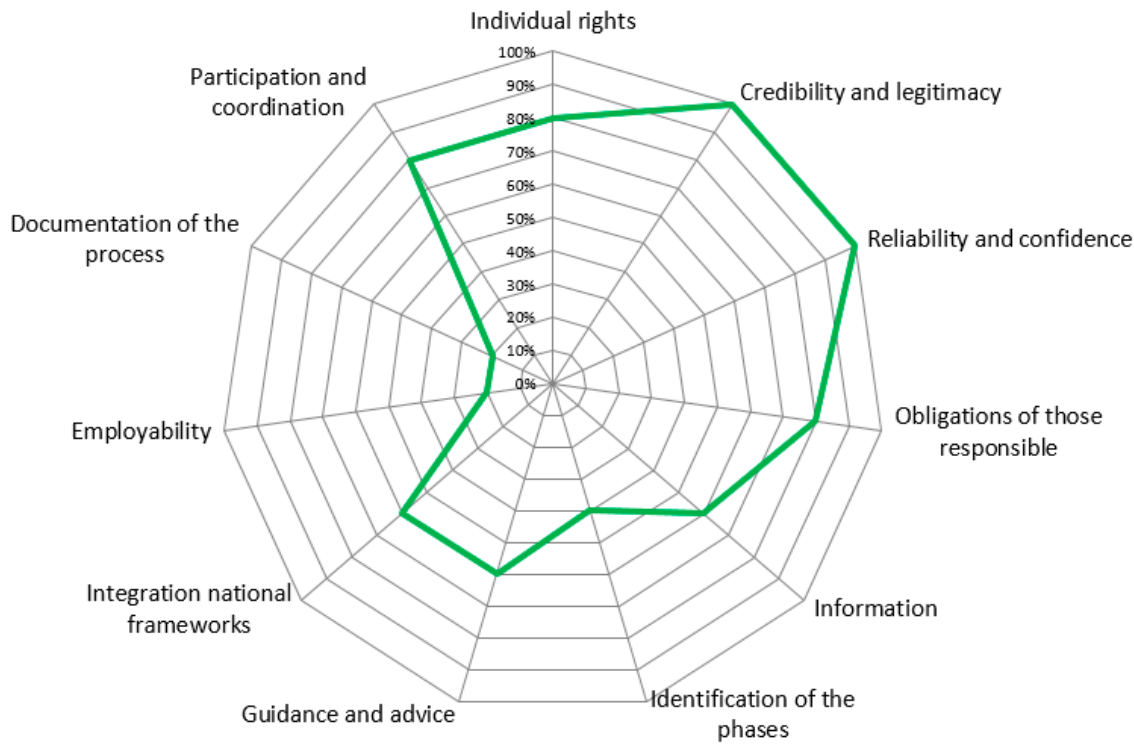

Figure 4. Percentage of the principles included in the different European recommendations.

Eighty percent of the rules display assurance of individual rights as well as obligations of those responsible. It should highlight that employability and process documentation are presented only in $20 \%$ of the references. The identification of the phases shows $40 \%$ and indicates the difference between the definition of strategic or political aspects and the operational. On the other hand, analysing from the perspective of the different recommendations, the upward trend can be clearly seen. In fact, the knowledge about the 
procedure has evolved, mainly through the Cedefop studies. All the elements described in the normative progression have gradually been introduced. The new directives of 2015 collected $100 \%$ of the principles and elements under analysis, which was the highest point of this development, see Figure 5. Finally, Figure 6 shows detail of the elements included in each regulation.

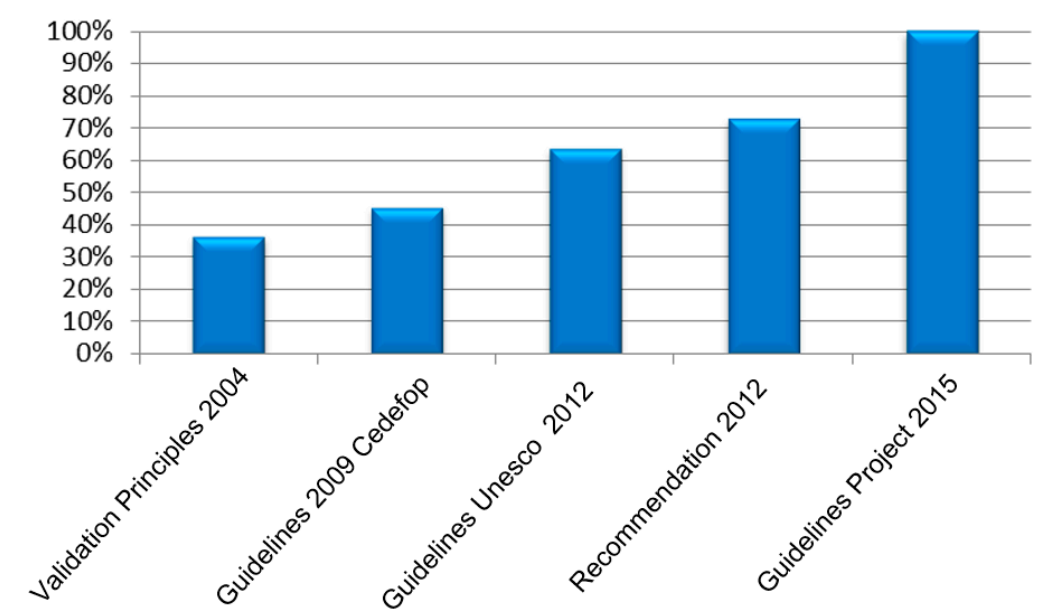

Figure 5. Percentage of the principles included in the different European recommendations.

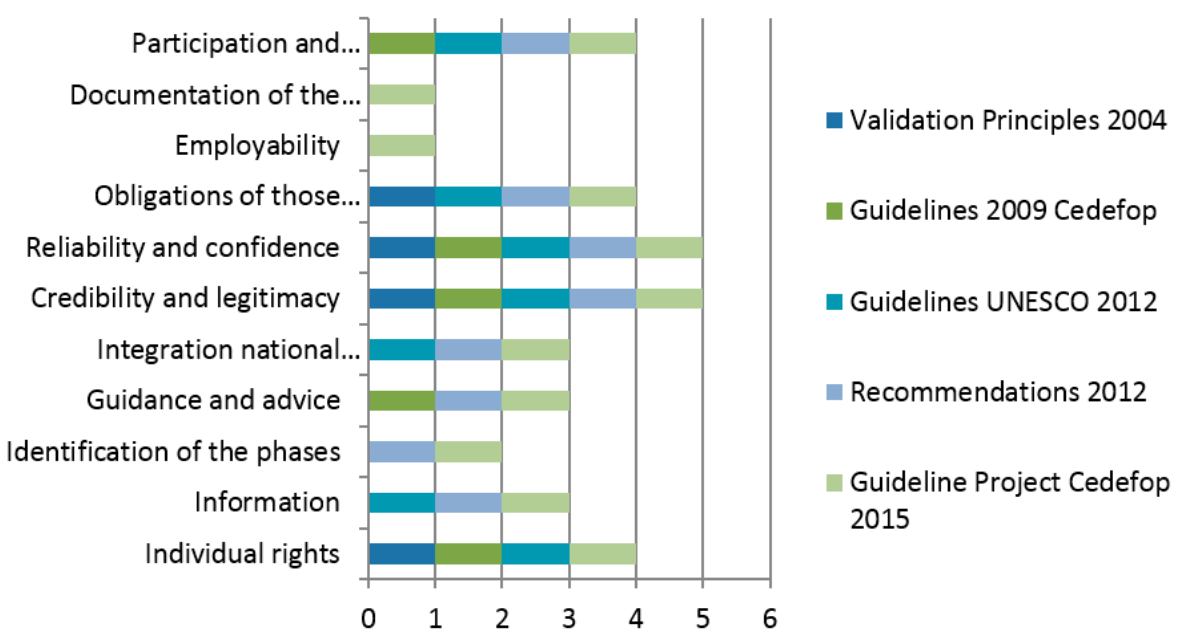

Figure 6. Principles and elements collected in each recommendation.

\subsection{Analysis of the Validation Principles in National Regulations}

This subsection is based on Table 4, which includes three aspects: the identification of the normative regulation (Table 6), the identification of reference frames that include the European and the national frames (Table 7), and finally, the principles and elements of the validation in Spanish regulations (Table 8). 
Table 6. Principles and validation elements in Spanish regulations. Regulation.

\begin{tabular}{|c|c|c|c|c|c|c|c|c|c|c|c|c|c|c|c|c|}
\hline & \multicolumn{16}{|c|}{ REGULATION } \\
\hline & \multicolumn{6}{|c|}{ Data } & \multicolumn{2}{|c|}{ Type } & \multicolumn{4}{|c|}{ Competent organ } & \multicolumn{4}{|c|}{ Rank } \\
\hline National Regulations & రి & ठ̊̀े & $\stackrel{\circ}{\stackrel{\sim}{*}}$ & $\overrightarrow{\text { ते }}$ & $\stackrel{\widetilde{\sigma}}{\sigma}$ & $\stackrel{m}{\vec{N}}$ & 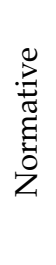 & 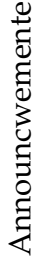 & 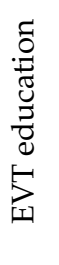 & 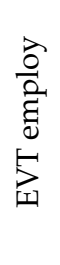 & $\begin{array}{l}\vec{\equiv} \\
\stackrel{0}{0}\end{array}$ & 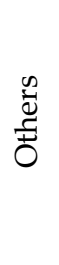 & 总 & 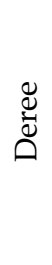 & $\begin{array}{l}\frac{\tilde{\Xi}}{\tilde{D}} \\
0\end{array}$ & 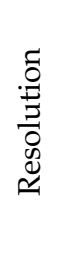 \\
\hline Law 5/2002 (Consolidated) & $x$ & & & & & & $x$ & & & & $x$ & & $x$ & & & \\
\hline Royal Decree 1224/2009 & & $x$ & & & & & $x$ & & & & $\mathrm{x}$ & & $x$ & $x$ & & \\
\hline ORDER PRE 910/2011 & & & & $x$ & & & $x$ & & & & $x$ & & & & $x$ & \\
\hline ORDER PRE 3480/2011 & & & & $\mathrm{x}$ & & & $x$ & & & & $\mathrm{x}$ & & & & $x$ & \\
\hline
\end{tabular}

Table 7. Principles and validation elements in Spanish regulations. Frameworks.

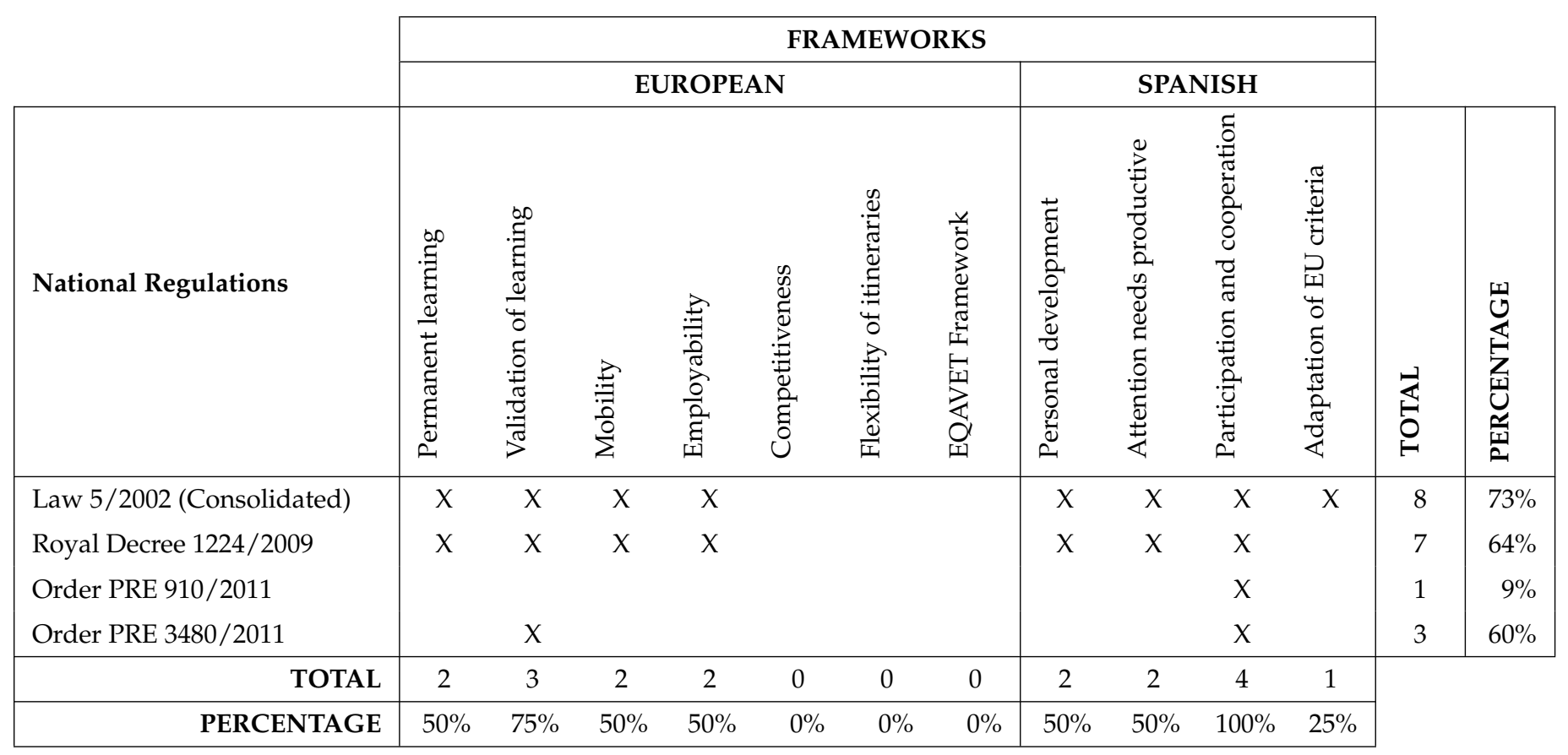


Table 8. Principles and validation elements in Spanish regulations. Principles.

\begin{tabular}{|c|c|c|c|c|c|c|c|c|c|c|}
\hline & \multicolumn{8}{|c|}{ PRINCIPLES OF VALIDATION } & \multirow[b]{2}{*}{ 兒 } & \multirow[b]{2}{*}{ 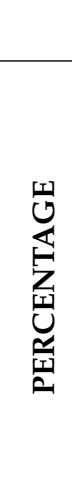 } \\
\hline National Regulations & 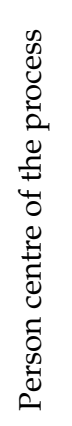 & 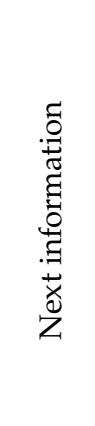 & 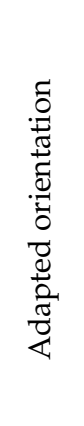 & 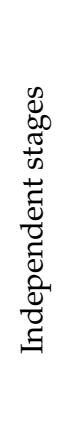 & 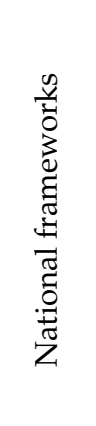 & 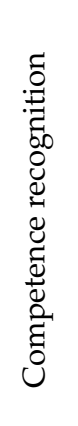 & 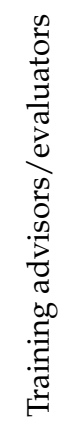 & 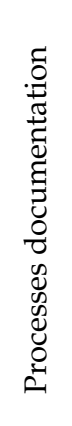 & & \\
\hline Law 5/2002 (Consolidated) & & $x$ & $x$ & & $x$ & $x$ & $x$ & & 8 & $73 \%$ \\
\hline Royal Decree 1224/2009 & & $x$ & $X$ & & $X$ & $x$ & $x$ & & 7 & $64 \%$ \\
\hline Order PRE 910/2011 & & $x$ & & & $x$ & & & & 1 & $9 \%$ \\
\hline Order PRE 3480/2011 & & $X$ & & & $x$ & $x$ & $x$ & & 3 & $60 \%$ \\
\hline TOTAL & 0 & 4 & 2 & & 1 & 3 & 3 & 0 & & \\
\hline PERCENTAGE & $0 \%$ & $100 \%$ & $50 \%$ & $0 \%$ & $100 \%$ & $75 \%$ & $75 \%$ & $0 \%$ & & \\
\hline
\end{tabular}

Once the reference regulation has been typified, its origin and its traceability is identified. The used reference frames are analysed as well as the attributes that they include, Table 7.

The attributes existence of the European framework can be analysed (see Figure 7); the validation framework for learning is the most referenced ( $75 \%)$; subsequently, mobility, lifelong learning and employability (50\%) follow. It should be noted that this last one was only included in $20 \%$ of the European recommendations, which provides a relevant indication of the utility that is conceded to the accreditation of competences in Spain.

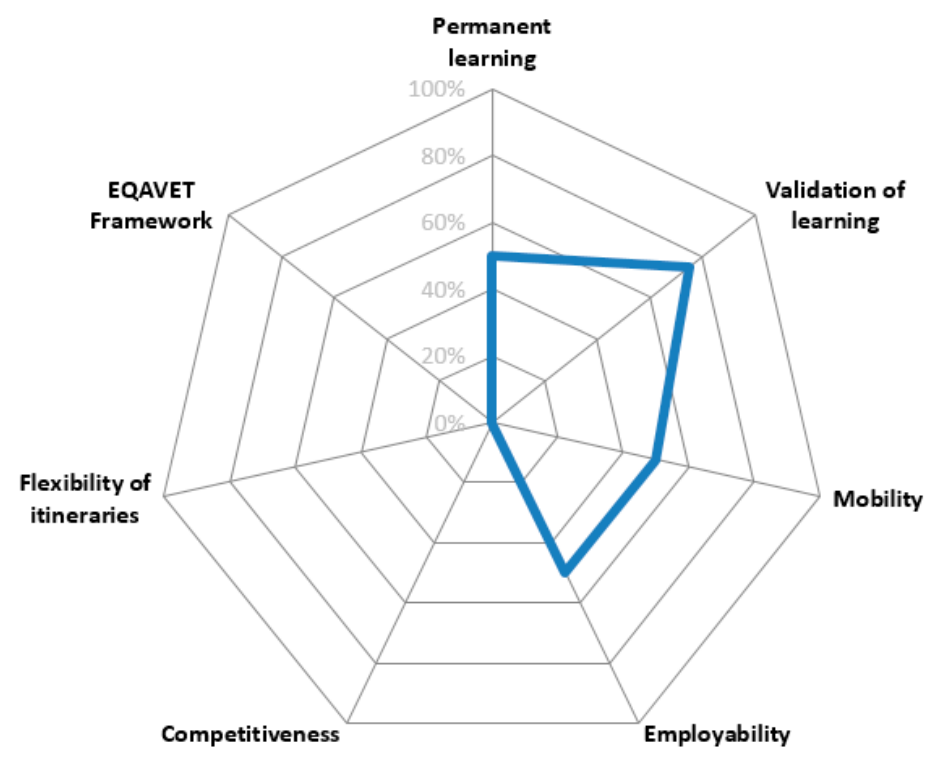

Figure 7. Percentage European reference framework according to Spanish regulations.

The Spanish framework is also analysed. Participation is set up as an essential element $(100 \%)$, then the requirement to conform the needs of the productive sectors and the centrality in the person (both $50 \%$ ), and finally, the adaptation to European validation frameworks $(25 \%)$ collected only in Law $5 / 2002$ on qualifications. The key is that the publication of Royal Decree (RD) 1224/2009 [23] was prior to the guidelines of Cedefop [33] 
and Council Recommendation on the validation of learning [36]. As a summary, Figure 8 shows the attributes of each recommendation.

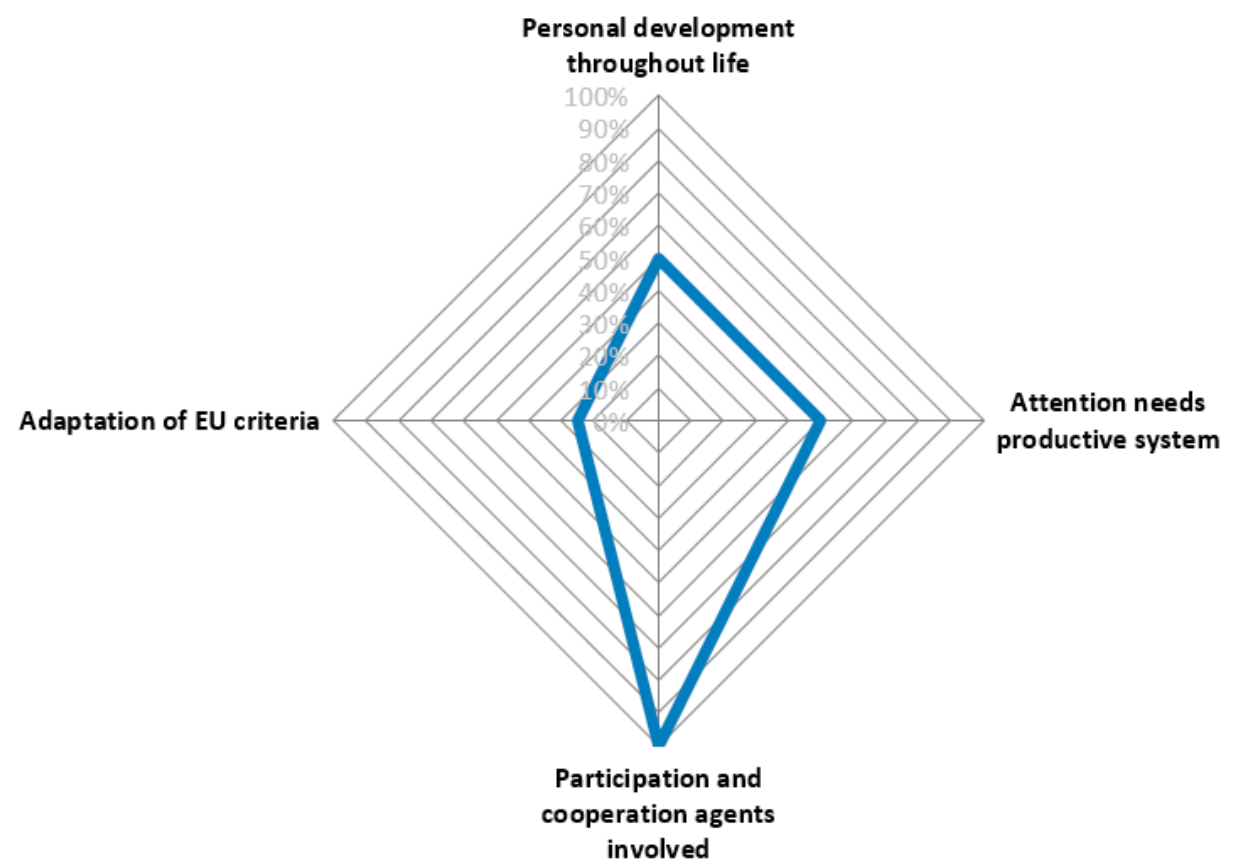

Figure 8. Percentage Spanish reference framework according to Spanish regulations.

The analysis shows that two aspects determine the nature of accreditation in Spain: information and integration in national frameworks $(100 \%)$. These two are the instruments of the national qualifications system and VET regulated by Law 5/2002 on qualifications [55], which sets out a system of information and guidance. On the other hand, the national catalogue of professional qualifications was established as an integrating element of the entire training proposal in VET, as well as for the accreditation of competences. The need for the recognition of competences and the training of human resources responsible for assessment and evaluation presented a significant importance (75\%). Figure 9 displays the validation principles collected.

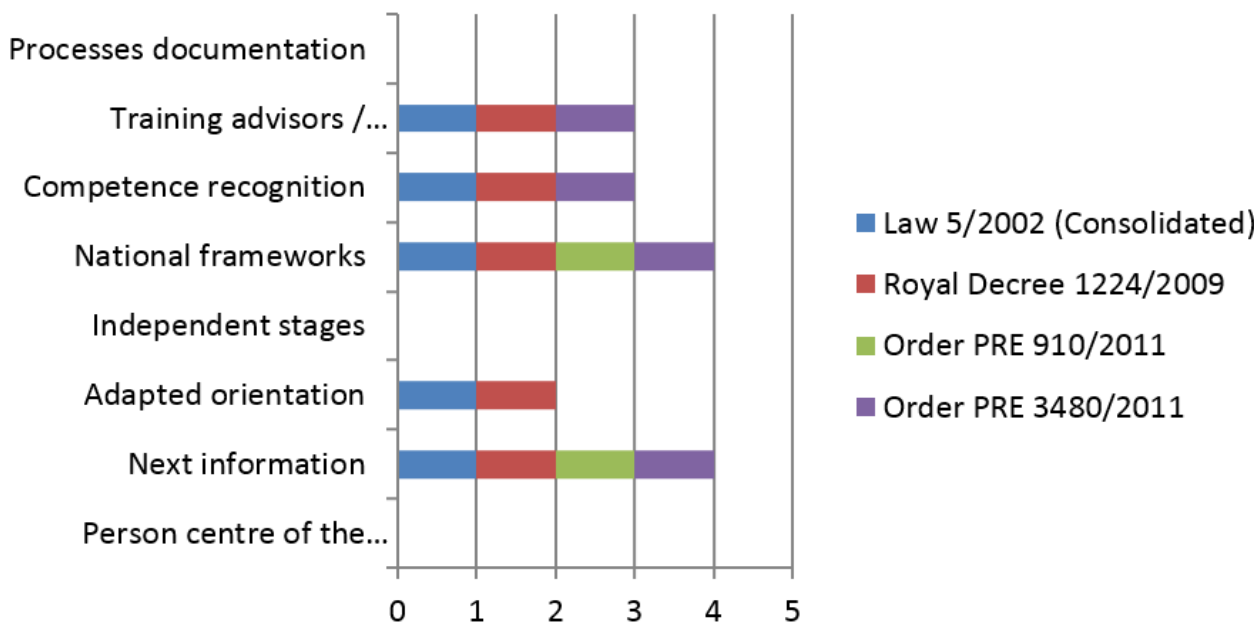

Figure 9. Percentage existence of validation principles in each Spanish regulation.

It should be highlighted that the person is not determined as the centre of the process in any regulation as well as the documentation of the processes-items that determine two of the strategic objectives that were established in the model. These include the detection 
of the citizen needs and the establishment of a documentary system based on processes. The methodology has provided the determination of the validation principles, through the tables and graphs. In this manner, the validation of non-formal and informal learnings acquired by professional experience in Europe as well as Spain has been characterized.

As a result, the accreditation of competences procedure in Spain can be carried out through an implementation of a process-based management system. See Tables 9 and 10.

Table 9. Cause-effect relationships between objectives (a).

\begin{tabular}{|c|c|c|c|c|c|c|c|c|c|c|c|c|c|c|c|c|c|c|c|c|c|}
\hline & & \multicolumn{13}{|c|}{ STRATEGY } & \multicolumn{7}{|c|}{ RESOURCES AND SYSTEMS } \\
\hline & & 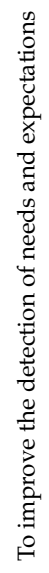 & 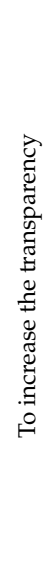 & 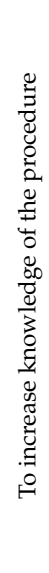 & 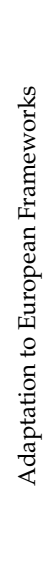 & 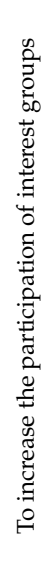 & 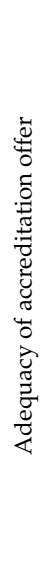 & 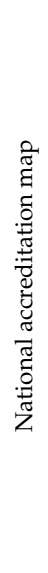 & 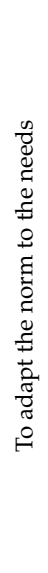 & 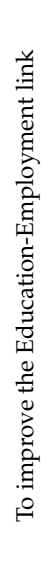 & 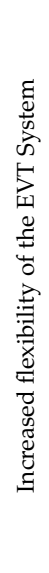 & 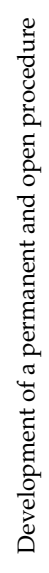 & 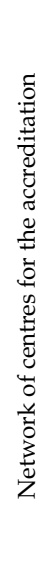 & 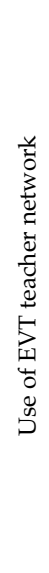 & 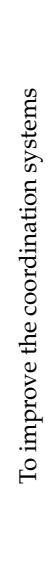 & 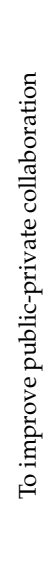 & 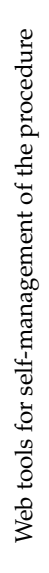 & 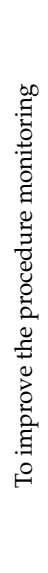 & 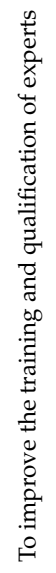 & 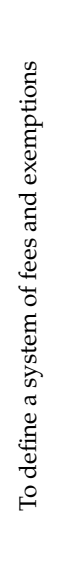 & 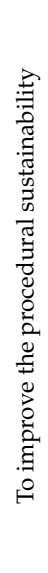 \\
\hline \multirow{10}{*}{ 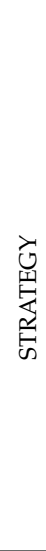 } & $\begin{array}{l}\text { To improve the detection of needs and } \\
\text { expectations }\end{array}$ & & $X$ & $x$ & & & & & & & & & & & & & & & & & \\
\hline & To increase the transparency & & & & & & & $x$ & & & & & & & & & & & & & \\
\hline & $\begin{array}{l}\text { To increase knowledge of the } \\
\text { procedure }\end{array}$ & & $x$ & & & & & & & & & & & & & & & & & & \\
\hline & Adaptation to European Frameworks & & & & & & & & $x$ & & & & & & & & & & & & \\
\hline & $\begin{array}{l}\text { To increase the participation of interest } \\
\text { groups }\end{array}$ & & & & & & & & & & & & & & & & & & & & \\
\hline & Adequacy of accreditation offer & & & & & & & & & & $\mathrm{X}$ & & & & & & & & & & \\
\hline & National accreditation map & & & & & & $\mathrm{X}$ & & & & & $\mathrm{X}$ & & & & & & & & & \\
\hline & To adapt the norm to the needs & & & & & & & & & $X$ & & & & & & & & & & & \\
\hline & $\begin{array}{l}\text { To improve the } \\
\text { Education-Employment link }\end{array}$ & & & & & & & & & & $X$ & & & & & & & & & & \\
\hline & Increased flexibility of the EVT System & & & & & & & & & & & & & & & & & & & & \\
\hline \multirow{10}{*}{ 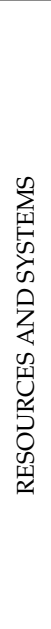 } & $\begin{array}{l}\text { Development of a permanent and } \\
\text { open procedure }\end{array}$ & & & & & & & & & & & & & & & & $x$ & & & & \\
\hline & $\begin{array}{l}\text { Network of centres for the } \\
\text { accreditation }\end{array}$ & & & & & & & & & & & & & $x$ & & & & $\mathrm{X}$ & $\mathrm{X}$ & & \\
\hline & Use of EVT teacher network & & & & & & & & & & & & $x$ & & & & & & $x$ & & \\
\hline & To improve the coordination systems & & & & & & & & & & & & & $x$ & & $X$ & & & & & \\
\hline & $\begin{array}{l}\text { To improve public-private } \\
\text { collaboration }\end{array}$ & & & & & & & & & & & & & & $\mathrm{X}$ & & & & & & $X$ \\
\hline & $\begin{array}{l}\text { Web tools for self-management of the } \\
\text { procedure }\end{array}$ & & & & & & & & & & & & & & & & & $\mathrm{X}$ & & & \\
\hline & To improve the procedure monitoring & & & & & & & & & & & & & & & & & & & & \\
\hline & $\begin{array}{l}\text { To improve the training and } \\
\text { qualification of experts }\end{array}$ & & & & & & & & & & & & & & & & & & & & \\
\hline & $\begin{array}{c}\text { To define a system of fees and } \\
\text { exemptions }\end{array}$ & & & & & & & & & & & & & & & & & & & & $X$ \\
\hline & $\begin{array}{l}\text { To improve the procedural } \\
\text { sustainability }\end{array}$ & & & & & & & & & & & & & & & & & & & & \\
\hline
\end{tabular}


Table 10. Cause-effect relationships between objectives (b).

\begin{tabular}{|c|c|c|c|c|c|c|c|c|c|c|c|c|c|c|c|c|}
\hline & & \multicolumn{11}{|c|}{ ACREDITATION PROCESS } & \multicolumn{4}{|c|}{ RESULTS } \\
\hline & & 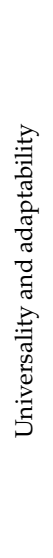 & 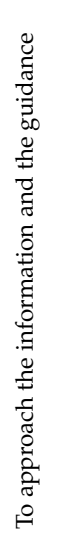 & 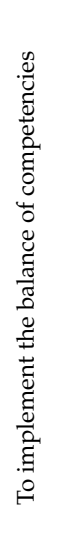 & 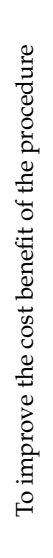 & 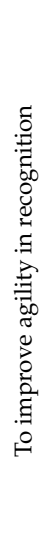 & 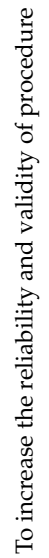 & 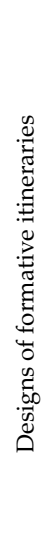 & 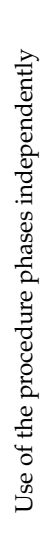 & 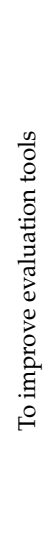 & 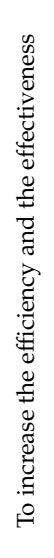 & 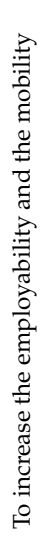 & 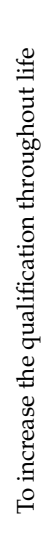 & 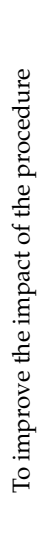 & 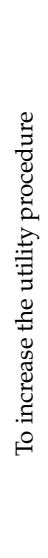 & 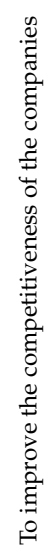 \\
\hline \multirow{10}{*}{ 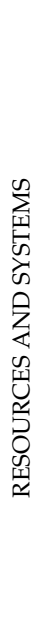 } & $\begin{array}{l}\text { Development of a permanent and } \\
\text { open procedure }\end{array}$ & & & & & & & & & & & & & & & \\
\hline & Network of centres for accreditation & & & & & & & & & & & & & & & \\
\hline & Use of EVT teacher network & & & & & & & & & & & & & & & \\
\hline & To improve coordination systems & & & & & & & & & & & & & & & \\
\hline & $\begin{array}{l}\text { To improve the public-private } \\
\text { collaboration }\end{array}$ & & & & & & & & & & & & & & & \\
\hline & $\begin{array}{l}\text { Web tools for self-management of } \\
\text { the procedure }\end{array}$ & & $x$ & & & & $x$ & & & & & & & & & \\
\hline & $\begin{array}{l}\text { To improve the procedure } \\
\text { monitoring }\end{array}$ & & & & & & & & & & & & & & & \\
\hline & $\begin{array}{l}\text { To improve the training and } \\
\text { qualification of experts }\end{array}$ & & & $x$ & & & & & & & & & & & & \\
\hline & $\begin{array}{c}\text { To define a system of fees and } \\
\text { exemptions }\end{array}$ & & & & $x$ & & & & & & & & & & & \\
\hline & $\begin{array}{l}\text { To improve procedural } \\
\text { sustainability }\end{array}$ & & & & & & & & & & & & & & & \\
\hline \multirow{10}{*}{ 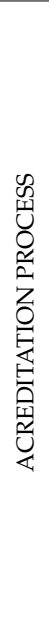 } & Universality and adaptability & & & & & & & & & & & & & & & \\
\hline & $\begin{array}{l}\text { To approach the information and } \\
\text { guidance }\end{array}$ & & & & & & & & & & & & & & & \\
\hline & $\begin{array}{l}\text { To implement the balance of } \\
\text { competencies }\end{array}$ & & & & & & & & $x$ & & & & & & & \\
\hline & $\begin{array}{l}\text { To improve the cost benefit of the } \\
\text { procedure }\end{array}$ & & & & & & & & & & & & & & & \\
\hline & $\begin{array}{l}\text { To improve the agility in the } \\
\text { recognition }\end{array}$ & & & & & & & & & & & & & & & \\
\hline & $\begin{array}{c}\text { To increase the reliability and the } \\
\text { validity of procedure }\end{array}$ & & & & & & & & & & & & & $\mathrm{X}$ & & \\
\hline & Designs of formative itineraries & & & & & & & & & & & $\mathrm{X}$ & $x$ & & & \\
\hline & $\begin{array}{l}\text { Use of the procedure phases } \\
\text { independently }\end{array}$ & & & & & & & & & & & & & & $x$ & \\
\hline & To improve evaluation tools & & & & & & & & & & $x$ & & & & & \\
\hline & $\begin{array}{l}\text { To increase the efficiency and the } \\
\text { effectiveness }\end{array}$ & & & & & & & & & & & & & $\mathrm{X}$ & & $x$ \\
\hline \multirow{5}{*}{ 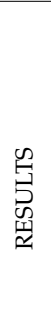 } & $\begin{array}{l}\text { To increase the employability and } \\
\text { the mobility }\end{array}$ & & & & & & & & & & & & & & & \\
\hline & $\begin{array}{l}\text { To increase the qualification } \\
\text { throughout life }\end{array}$ & & & & & & & & & & & $\mathrm{X}$ & & & & \\
\hline & $\begin{array}{l}\text { To improve the impact of the } \\
\text { procedure }\end{array}$ & & & & & & & & & & & & $x$ & & $x$ & \\
\hline & To increase the utility procedure & & & & & & & & & & & & & & & $x$ \\
\hline & $\begin{array}{l}\text { To improve the competitiveness of } \\
\text { the companies }\end{array}$ & & & & & & & & & & & & & & & \\
\hline
\end{tabular}




\section{Discussion}

Few countries have established quality codes or guidelines on validation, and the question remains as to whether quality assurance procedures and systems are effectively capable of guaranteeing reliable, valid, and credible evaluations [16]. However, the acceptation and achievement of a qualifications approach established on learning results improves the situation of non-formal and informal learning in the labour market and society. Validation must be an instrument to improve employability and learning throughout life, particularly for people with low qualifications and, therefore, with greater difficulties in the labour market [56]. Thus, national qualifications frameworks are essential tools for the accessibility to the procedure, the transfer and accumulation of learning outcomes, and the application in VET systems [57].

The methodology consisted of three parts: definition of the investigation, research work or field work, and analysis of the results. This requires the development of working groups, exchange of research aims, and the management of all documentation that is used in the method. The entire procedure for the collection of this information has been processed to ensure homogeneity in the request, the management of the information, and research. For the methodological implementation of the second phase of the research, two tools were considered: qualitative and quantitative [58]. The documentary analysis has been used in the qualitative part to derive the main aspects of the whole documentation which will be reviewed with the goal to synthesize the common elements in the scope of the study.

In the study of the outcomes, the complexity consists of the integration of quantitative and qualitative results, which are determined from the surveys of the Autonomous Communities regarding the different phases of the procedure. The final aim was to identify the results of the procedure operation. Qualitative information processing was done using SWOT analysis. This was carried out to establish the applicable points and the improvement areas of the same as a starting point for the realization of a proposal of management system model based on processes for the accreditation procedure of competencies in Spain.

The analysis of the validation principles in European recommendations and national regulations has allowed characterizing the validation of the learning obtained by professional experience and in non-formal and informal settings, allowing to set up the development of the accreditation process of competences in Spain. As a result, these works open the door to the deepening of research in the quality management field of the validation procedure in EU and Spain [59,60].

Author Contributions: P.M., A.R. and L.C. conceived of the presented idea and designed the work, P.M. carried out data collection and literature review. A.R. and S.C. proposed the initial structure of the article and planned the methodology. S.C. carried out the presentation of the results after their interpretation, carried out in conjunction with P.M., A.R. and L.C. The final critical review was conducted by S.C., A.R. and L.C. All authors have read and agreed to the published version of the manuscript.

Funding: This research received no external funding.

Institutional Review Board Statement: Not applicable.

Informed Consent Statement: Not applicable.

Data Availability Statement: https://incual.educacion.gob.es/documents/35348/80300/Datos_ Proc_Acre_2013_impre/ad122388-a2b9-4692-97ab-a14907613d2b (accessed on 28 June 2021).

Conflicts of Interest: The authors declare no conflict of interest.

\section{References}

1. Terokhina, N. Recognition of the Results of Non-Formal Adult Education: American Experience. Sci. Educ. 2017, $25,80-85$. [CrossRef]

2. European Centre for the Development of Vocational Training. The Benefits of Vocational Education and Training; Publications Office of the European Union: Luxembourg, 2011. 
3. Keeton, M.T. Experiential Learning; Jossey Bass: San Francisco, CA, USA, 1984.

4. Harris, J. Prior Learning Assessment: Does Dewey's Theory Offer Insight? Prior Learning Assessment: Does Dewey's Theory Offer Insight? New Dir. Adult Contin. Educ. 2018, 158, 77-86. [CrossRef]

5. Moss, L. A Review of Recognition of Prior Learning (RPL) Literature in Quebec. Can. J. Study Adult Educ. 2017, $30,47-63$.

6. Aarkrog, V.; Wahlgren, B. Assessment of Prior Learning in Adult Vocational Education and Training. Int. J. Res. Vocat. Educ. Train. 2015, 2. [CrossRef]

7. Paulos, C. Qualification of Adult Educators in Europe: Insights from the Portuguese Case. Int. J. Res. Vocat. Educ. Train. 2015, 2. [CrossRef]

8. Guimarães, P. Reflections on the Professionalisation of Adult Educators in the Framework of Public Policies in Portugal. Eur. J. Educ. 2009, 44, 205-219. [CrossRef]

9. Rienzo, P.D. Recognition and Validation of Non Formal and Informal Learning: Lifelong Learning and University in the Italian Context. J. Adult Contin. Educ. 2014, 20,39-52. [CrossRef]

10. Snyman, M.; van den Berg, G. The Significance of the Learner Profile in Recognition of Prior Learning. Adult Educ. Q. 2018, 68, 24-40. [CrossRef]

11. Werquin, P. The Missing Link to Connect Education and Employment: Recognition of Non-Formal and Informal Learning Outcomes. J. Educ. Work 2012, 25, 259-278. [CrossRef]

12. Guisan Weber, S.; Voit, J.; Lengauer, S.; Proinger, E.; Duvekot, R.; Aagaard, K. Cooperate to Validate: OBSERVAL-NET Experts' Report on Validation of Non-Formal and Informal Learning (VNFIL); Research Report; European University Continuing Education Network (EUCEN): Barcelona, Spain, 2014. Available online: https: / / eric.ed.gov/?id=ED559370 (accessed on 1 May 2021).

13. European Centre for the Development of Vocational Training. European Inventory on Validation of Non-Formal and Informal Learning: 2016 Update; Synthesis Report; Publications Office of the European Union: Luxembourg, 2017.

14. Álvarez Bermúdez, N. European Inventory on Validation of Non-Formal and Informal Learning 2014: Country Report Spain; ICF International: Thessaloniki, Greece, 2014.

15. European Centre for the Development of Vocational Training; European Commission; ICF. European Inventory on Validation of Non-Formal and Informal Learning 2018 Update; Synthesis Report; European Centre for the Development of Vocational Training: Luxembourg, 2019.

16. European Centre for the Development of Vocational Training; European Commission; Villalba-Garcia, E.; Endrodi, G.; Murphy, I.; Scott, D.; Souto-Otero, M. European Inventory on Validation of Non-Formal and Informal Learning: 2018 Update: Executive Summmary; Final Synthesis Report; Publications Office of the European Union: Luxembourg, 2020.

17. Dahler, A.M.; Grunnet, H. Quality in Validation in the Nordic Countries. Final Report for "Quality in the Nordic Countries-A Mapping Project"; National Knowledge Centre for Validation of Prior Learning: Aarhus, Denmark, 2012.

18. Kleef, J.V. Kvalitet I vurdering og anerkendelse af realkompetencer. In Anerkendelse af Realkompetencer-En Antologi; Aagaard, K., Enggaard, E., Grunnet, H., Larsen, J., Dahler, A.M., Duvekot, R., Helms, N.H., Høyrup, S., Larsen, N., Nordentoft, A., et al., Eds.; VIA Systime: Åarhus, Denmark, 2011.

19. European Commission. Declaration of the European Ministers of Vocational Education and Training, and the European Commission, convened in Copenhagen on 29 and 30 November 2002, on enhanced European cooperation in vocational education and training-'The Copenhagen Declaration'. Available online: https://eur-lex.europa.eu/legal-content/EN/TXT/?uri= LEGISSUM:ef0018 (accessed on 1 May 2021).

20. European Commission. Maastricht Communiqué on the Future Priorities of Enhanced European Cooperation in Vocational Education and Training (VET) (Review of the Copenhagen Declaration of 30 November 2002). Available online: http:/ / ec.europa. eu/education/news/ip/docs/maastricht_com_en.pdf (accessed on 1 May 2021).

21. European Commission. Draft Conclusions of the Council and of the Representatives of the Governments of the Member States Meeting within the Council on Common European Principles for the Identification and Validation of Non-Formal and Informal Learning (9175/04 EDUC 101 SOC 220); European Commission: Brussels, Belgium, 2004.

22. European Commission. Presidency Conclusions Barcelona European Council 15 and 16 March 2002. Available online: https: / / ec.europa.eu/commission/presscorner/detail/en/PRES_02_930 (accessed on 1 May 2021).

23. Real Decreto 1224/2009, de 17 de Julio, de Reconocimiento de Las Competencias Profesionales Adquiridas Por Experiencia Laboral. BOE 2009, 205, 72704-72727.

24. Carro, L. Country Report Spain. 2016 Update to the European Inventory on Validation of Non-Formal and Informal Learning; ICF International: Thessaloniki, Greece, 2016.

25. European Centre for the Development of Vocational Training. Cedefop European Public Opinion Survey on Vocational Education and Training; Publications Office of the European Union: Luxembourg, 2017.

26. European Centre for the Development of Vocational Training. European Guidelines for Validating Non-Formal and Informal Learning; Publications Office of the European Union: Luxembourg, 2015.

27. Bjørnavold, J. Making Learning Visible: Identification, Assessment and Recognition of Non-Formal Learning in Europe; Publications Office of the EU: Luxembourg, 2000.

28. European Commission. White Paper on Education and Training. Teaching and Learning. Towards the Learning Society; European Commission: Brussels, Belgium, 1995. 
29. European Commission. Directive 2005/36/EC of the European Parliament and of the Council of 7 September 2005 on the Recognition of Professional Qualifications. Off. J. Eur. Union L 2005, 255, 22.

30. European Commission. The Bordeaux Communiqué on Enhanced European Cooperation in Vocational Education and Training. Communiqué of the European Ministers of Vocational Education and Training, the European Social Partners and the European Commission Convened in Bordeaux on November 262008 to Review the Priorities and Strategies of the Copenhagen Process; European Commission: Brussels, Belgium, 2008.

31. European Centre for the Development of Vocational Training. European Training Thesaurus; Office for Official Publications of the European Communities: Luxembourg, 2008; Available online: https:/ /www.cedefop.europa.eu/files/3049_en.pdf (accessed on 1 May 2021).

32. European Commission. EUROPE 2020 A Strategy for Smart, Sustainable and Inclusive Growth; European Commission: Brussels, Belgium, 2010.

33. European Centre for the Development of Vocational Training. European Guidelines for Validating Non-formal and Informal Learning; Publications Office of the European Union: Luxembourg, 2009.

34. European Commission. The Bruges Communiqué on enhanced European Cooperation in Vocational Education and Training for the period 2011-2020. Communiqué of the European Ministers for Vocational Education and Training, the European Social Partners and the European Commission, Meeting in Bruges on 7 December 2010 to Review the Strategic Approach and Priorities of the Copenhagen Process for 20112020; European Commission: Brussels, Belgium, 2010; Available online: https://www.cedefop.europa.eu/files/bruges_en.pdf (accessed on 1 May 2021).

35. UNESCO. UNESCO Guidelines for the Recognition, Validation and Accreditation of the Outcomes of Non-Formal and Informal Learning; UNESCO Institute for Lifelong Learning: Hamburg, Germany, 2012.

36. European Commission. Council Recommendation of 20 December 2012 on the Validation of Non-Formal and Informal Learning. Off. J. Eur. Union C 2010, 398, 1.

37. Bjørnavold, J. Validation of Non-Formal and Informal Learning in Europe. The Challenging Move from Policy to Practice; The European Centre for the Development of Vocational Training (Cedefop): Rotterdam, The Netherlands, 2014.

38. Serreri, P. El Balance de Competencias y la Orientación Profesional: Teoría y Práctica. Reflexiones en Torno al Balance de Competencias: Concepto y Herramientas para la Construcción del Proyecto Profesional. In Reflexiones en Torno al Balance de Competencias: Concepto y Herramientas para la Construcción del Proyecto Profesional; Figuera Gazo, P., Rodríguez Moreno, M.L., Eds.; Publicacions i Edicions Universitat de Barcelona: Barcelona, Spain, 2007; pp. 15-37.

39. European Commission. Recommendation of the European Parliament and of the Council of 18 June 2009 on the Establishment of a European Credit System for Vocational Education and Training (ECVET). Off. J. Eur. Union C 2009, 155, 11.

40. Misko, J. Regulating and Quality Assuring VET: International Developments; National Centre for Vocational Education Research: Adelaide, Australia, 2015.

41. Kreysing, M. Vocational Education in the United States: Reforms and Results. Vocat. Train. Eur. J. 2001, 23, 27-35.

42. Pilz, M. Training Patterns of German Companies in India, China, Japan and the USA: What Really Works? Int. J. Res. Vocat. Educ. Train. 2016, 3. [CrossRef]

43. Pilz, M.; Li, J. Tracing Teutonic Footprints in VET around the World? The Skills Development Strategies of German Companies in the USA, China and India. Eur. J. Train. Dev. 2014, 38, 745-763. [CrossRef]

44. Hoffman, N.; Schwartz, R. Gold Standard: The Swiss Vocational Education and Training System. International Comparative Study of Vocational Education Systems; National Center on Education and the Economy: Geneve, Switzerland, 2015.

45. Pilz, M. Typologies in Comparative Vocational Education: Existing Models and a New Approach. Vocat. Learn. 2016, 9, 295-314. [CrossRef]

46. Balestrini Acuña, M. Como se Elabora el Proyecto de Investigación: (Para los Estudios Formulativos o Exploratorios, Descriptivos, Diagnósticos, Evaluativos, Formulación de Hipótesis Causales, Experimentales y los Proyectos Factibles); Consultores Asociados BL: Caracas, Venezuela, 2006.

47. Pérez, M.S.; Seco, M.P. La Excelencia Operativa en la Administración Pública: Creando Valor Público: Guía Para la Implantación de la Gestión Basada en Procesos en la Administración Pública; Instituto Nacional de Administración Pública: Madrid, Spain, 2014.

48. Peña, D. Fundamentos de Estadística; Bisquerra Alzina, R., Ed.; La Muralla: Madrid, Spain, 2014.

49. Mejía Navarrete, J. Sobre La Investigación Cualitativa. Nuevos Conceptos y Campos de Desarrollo. Investig. Soc. 2014, 8, 277-299. [CrossRef]

50. Strauss, A.L.; Corbin, J. Bases de la Investigación Cualitativa: Técnicas y Procedimientos para Desarrollar la Teoría Fundamentada; Universidad de Antioquía: Medellín, Colombia, 2012.

51. Vilà, R.; Bisquerra Alzina, R. El análisis cuantitativo de los datos. In Metodología de la Investigación Educativa; Bisquerra Alzina, R., Ed.; La Muralla: Madrid, Spain, 2004; pp. 259-271.

52. Denzin, N.K.; Lincoln, Y.S. Manual de Investigación Cualitativa; Gedisa: Barcelona, Spain, 2012.

53. Argibay, J.C. Muestra en Investigación Cuantitativa. Subj. Procesos Cogn. 2009, 13, 13-29.

54. Gan Bustos, F.; Triginé Prats, J. Análisis y Problemas en la Toma de Decisiones; Editorial Díaz de Santos: Barcelona, Spain, 2013.

55. Ley Orgánica 5/2002, de 19 de Junio, de Las Cualificaciones y de La Formación Profesional. Boletín Of. del Estado 2002, 147, 20.

56. Chisvert-Tarazona, M.J.; Ros-Garrido, A.; Abiétar-López, M.; Carro, L. Context of Validation of Non-Formal and Informal Learning in Spain: A Comprehensive View. Int. J. Lifelong Educ. 2019, 38, 198-213. [CrossRef] 
57. European Centre for the Development of Vocational Training. Overview of National Qualifications Framework Developments in Europe 2020; Publications Office of the European Union: Luxembourg, 2021.

58. Zawacki-Richter, O.; Kerres, M.; Bedenlier, S.; Bond, M.; Buntins, K. Systematic Reviews in Educational Research: Methodology, Perspectives and Application; Springer Fachmedien Wiesbaden: Wiesbaden, Germany, 2020. [CrossRef]

59. Staboulis, M.; Sytziouki, S. Constructivist Policy Rational for Aligning Non-Formal and Informal Learning to Mechanism for Validation and Recognition of Skills: The Case of Cyprus. J. Educ. Soc. Policy 2021, 8, 68-76. [CrossRef]

60. Singh, S.; Ehlers, S. Recognition of Prior Learning. Andrag. Spoznanja 2019, 25, 69-87. [CrossRef] 